\title{
Taxonomic review of the genus Crambe sect. Crambe (Brassicaceae, Brassiceae)
}

\author{
by \\ Anibal Oscar Prina \\ Facultad de Agronomía, Universidad Nacional de La Pampa, C. C. 300, Santa Rosa, La Pampa, República Argentina \\ prina@agro.unlpam.edu.ar
}

\begin{abstract}
Prina, A. 2009. Taxonomic review of the genus Crambe sect. Crambe (Brassicaceae, Brassiceae). Anales Jard. Bot. Madrid 66(1): 7-24

The systematics of the genus Crambe L. sect. Crambe is reviewed, within which 16 species and 5 infraspecific taxa are considered, which are distributed from $\mathrm{E}$ and $\mathrm{N}$ Europe to Central Asia. A key for their identification is provided, along with a brief description, synonyms, distribution and habitat of each taxon. The infrageneric systematics of Crambe is discussed briefly. The following new combinations are proposed: Crambe edentula var. glabrata (Freyn \& Sintenis) Prina comb. nov. and C. orientalis subsp. sulphurea (Stapf ex O.E. Schulz) Prina stat. nov.
\end{abstract}

Keywords: Crambe, sect. Crambe, Brassicaceae, Brassiceae, taxonomy, Central Asia, Europe.

\section{Introduction}

The genus Crambe L. (Brassicaceae, Brassiceae) has an extensive area of distribution that goes from the Macaronesian archipelagoes to the West of China and North of India and from the Arctic Polar Circle on the Scandinavian Peninsula to $5^{\circ}$ Latitude South in the North of Tanzania. It has representation in the Macaronesian, Euro-Siberian, Mediterranean, SindicoSaharan, Irano-Turkish and Sudan-Zambezian (Ethiopia and Tanzania) regions (Leppik \& White, 1975).

Candolle (1821), based mainly on the dimensions and shape of the proximal joint of the fruit, made a first subdivision of the genus in three section: sect. Dendrocrambe DC., sect. Leptocrambe DC. and sect. Sarcocrambe DC. This infrageneric division closely corresponds to the geographical areas of distribution

\section{Resumen}

Prina, A. 2009. Revisión taxonómica del género Crambe sect. Crambe (Brassicaceae, Brassiceae). Anales Jard. Bot. Madrid 66(1): 7-24 (en inglés).

En el presente trabajo se revisa la sistemática del género Crambe L. sect. Crambe, que cuenta con 16 especies y 5 táxones infraespecíficos distribuidos desde el $\mathrm{E}$ y $\mathrm{N}$ de Europa hasta Asia central. Se proporcionan una clave para su identificación, una breve descripción de cada uno, los sinónimos, el hábitat y la distribución. Se discute brevemente la sistemática infragenérica del género Crambe. Se proponen las siguientes nuevas combinaciones: Crambe edentula var. glabrata (Freyn \& Sintenis) Prina comb. nov. y C. orientalis subsp. sulphurea (Stapf ex O.E. Schulz) Prina stat. nov.

Palabras clave: Crambe, sect. Crambe, Brassicaceae, Brassiceae, taxonomía, Asia central, Europa.

of the taxa it includes. Sect. Dendrocrambe is endemic to Macaronesia, Sect. Leptocrambe is distributed throughout the Mediterranean basin as far as the East of Africa and sect. Sarcocrambe has an area of distribution that goes from the East of Europe to the steppes and mountains of Central Asia. The type species of the genus (C. maritima L.) was designated by Green (1925) and belongs to sect. Sarcocrambe (Candolle, 1821) which thus becomes the typical section, Crambe sect. Crambe.

Later authors, such as Prantl (1891) and Schulz (1919) kept to this scheme without change, only adding new taxa described. Here we recognize the three sections: sect. Leptocrambe with 5 species and 5 infraspecific taxa (Prina, 1999), sect. Dendrocrambe with 14 species (Prina \& Martínez-Laborde, 2008), and sect. Crambe (三 sect. Sarcocrambe DC.), which is reviewed in this study. 


\section{Materials and methods}

The classical methodology used in plant taxonomy has been followed, based on the analysis of morphological characters of herbarium material from BM, E, EVIN, K, MA, MPU, VIR and W. In some cases we had living plants obtained from the seeds supplied by the U.S.D.A.-NCRPIS (United States Department of Agriculture-North Central Regional Plant Introduction) and the Bansem-UPM (Banco de Semillas de la Universidad Politécnica de Madrid), and grown in the Campos de Prácticas de la Escuela Técnica Superior de Ingenieros Agrónomos de la Universidad Politécnica de Madrid (ETSIA-UPM). For reasons of space, of the approximately 300 herbarium vouchers studied, only one sample per country is assigned for each taxon.

\section{Taxonomic treatment}

The species corresponding to sect. Crambe s.l., appear in the system proposed by Khalilov (1991a), distributed in four different sections: sect. Crambe s.str., sect. Orientecrambe I.I. Khalilov, sect. Astrocrambe I.I. Khalilov and sect. Flavocrambe I.I. Khalilov. The distinctive characters considered for sect. Orientecrambe are the fruits with a conspicuous, cylindershaped proximal joint, and an ellipsoidal, four-ribbed distal joint; but none of these traits are exclusive to the species included by Khalilov in this section. In a later study based on the characteristics of the pollen grain Khalilov \& Archangelsky (1991) recognizes that neither can these characters distinguish this section of sect. Crambe s. str.

Khalilov (1991b) subdivides sect. Orientecrambe into two subsections, subsect. Orientecrambe and the subsect. Junceae I.I. Khalilov differentiating between them by the presence of strengthened edges on the distal joint of the fruits (in subsection Orientecrambe) or their absence (in subsect. Junceae), in direct contradiction with the main trait with taxonomic value on which the creation of the new section was previously based.

The monotypic section Astrocrambe is characterised, according to the author, by its particular fasciculate hair indument, of $C$. shugnana Korsh. The presence of this type of indumenta has also been found in C. alutacea Hand.-Mazz., a species which Khalilov (1991a) does not mention in his work, which led to the preliminary solution of including this last species in the new section (Prina, 1998). However, neither do later taxonomic analysis of the entire genus (Prina, 2000) sustain sect. Astrocrambe; in fact, C. alutacea, apart from the traits of indument, is morphologically closer to C. orientalis L., C. koktebelica (A. Junge) N. Busch and C. hedgei I.I. Khalilov.
Khalilov (1991a) characterises his single species section Flavocrambe by the yellow petals of its single species, C. gordjaginii Sprygin \& Popov. While this colour of petals is rare in the genus, it is not exclusive to this species, as C. orientalis var. sulphurea O.E. Schulz and C. alutacea also have yellow petals. Furthermore the disposition of the indument and the leaf morphology of $C$. gordjaginii are closer to those of C. grossheimii I.I. Khalilov y C. edentula Korsch., which do not have yellow petals and which Khalilov (1991a, 1993) included in sect. Orientecrambe.

Finally, this same author also subdivided sect. Crambe s.str. into two subsections, subsect. Crambe and the subsect. Tatariae I.I. Khalilov, the latter characterised by the distal joint of the fruit recticulate and four-ribbed, but surprisingly without establishing the differences to subsect. Crambe. Thus Khalilov (1991b) places the latter in C. cordifolia Steven subsp. cordifolia and C. cordifolia subsp. kotschyana (Boiss.) Jafri ( $\equiv C$. kotschyana Boiss.), in spite of the fact that in both the distal joint of the fruit has four at least slightly strengthened edges. Once again there is a contradiction in considering the same diagnostic character which was already used to distinguish sect. Orientecrambe.

The phylogenetic studies based on genetic markers, specifically ITS, published by Francisco-Ortega \& al. $(1999,2002)$ are in agreement with the findings of the author of this article on the basis of morphological characters (Prina 1999, 2000) and do not support the infrageneric classification proposed by Khalilov (1991a, 1991b, 1993); we shall therefore follow here the generic systematics as proposed by Candolle (1821).

\section{KEYS OF SECTIONS}

1. Microphanaerophytes, nanophanaerophytes or chamaephytes; distal joint of the fruit acuminate

sect. Dendrocrambe

1. Hemicriptophytes, chamaephytes or terophytes; distal joint not acuminate ......................................................... 2

2. Annual or perennial plants, in this case escapose habit the latter with poorly-leaved vegetative stems and leafless stalks; distal joint of fruit 2.5-3 mm in diameter, proximal joint developed longitudinally, generally longer than broad

sect. Leptocrambe

2. Perennial plant in general not escapose habit generally with no leafless stalks, but foliated vegetative stems; distal joint of fruit (2.5)3-10 $\mathrm{mm}$ in diameter, proximal joint as broad as it is long

\section{Sect. Crambe}

三 sect. Sarcocrambe DC., Syst. Nat. 2: 650. 1821, nom. inval.

Hemicriptophytes or chamaephytes, from glabrous to densely pubescent, with either simple or fasciculate hairs. Fruit with proximal joint from obconical to cylin- 
der-shaped, poorly developed and sterile, except for $C$. shugnana and C. koktebelica, and the distal joint well developed, spheric or ellipsoidal, from four strengthened edges to \pm rugose, bearing a single seed. Spherical or bifacial seed, smooth testa or slightly reticulate, with highly developed surrounding funiculus.

\section{Key FOR THE SPECIES OF THE SECT. CRAMBE}

1. Fruit with distal joint 4-10 mm diameter ..................... 2

1. Fruit with distal joint 2.5-3(4) $\mathrm{mm}$ diameter ................. 9

2. Basal leaves $30-50 \mathrm{~cm}$, bearing long petioles, with either coriaceous or herbaceous blades, dark-green and cordate base; caudex of up to $20 \mathrm{~cm}$ diameter

2. Basal leaves $25-40(50) \mathrm{cm}$, short and with wide petioles, with either crass or coriaceous blade, frequently glaucus and with cuneate base; caudex absent or no greater than 4$5 \mathrm{~cm}$ in diameter.

3. Glabrous stems; rough blade, covered with stiff hairs, ovate-orbicular, irregularly pinnatisect, with assymetric lateral segments and terminal with profoundly cordate base; fruit with distal joint 4-5 $\mathrm{mm}$ in diameter

1a. C. cordifolia subsp. cordifolia

3. Stems sparsely haired; smooth blade, with very sparse and thin hairs, ovate-elliptic, from pinnatifid to irreguarly pinnatisect, distal joint kidney-shaped with slightly cordate base; fruit with distal joint 5-5.5 mm diameter

1b. C. cordifolia subsp. kotschyana

4. Fruit with spherical distal joint, smooth or dented, but without strengthened edges ........................................ 5

4. Fruit with four-sided distal joint, or spherical with 4 very prominent strengthened edges

5. Crass leaves, blade from pinnatifid to pinnatisect, ruffed margins, irregularly toothed; fruit with distal joint 6-10 mm diameter, with thick and cork-textured pericarp

2. C. maritima

5. Thin leaves, with pinnatifid blade, non-ruffed edge, entire margin; fruit with distal joint 5-7 mm in diameter, with thin and very stiff pericarp

3. C. pinnatifida

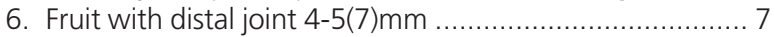

6. Fruit with distal joint $6-8 \mathrm{~mm}$.................................. 8

7. Almost hairless plants; glaucous leaves, smooth .................

4a. C. tataria var. tataria

7. Hirsute plants, even when mature; green leaves, rough to touch .................................. 4b C. tataria var. aspera

8. Cauline leaves with thin blade, 2-times pinnatipartite, narrow and acute lobes, glabrous; fruit with distal joint attenuate towards apex

5. C. steveniana

8. Cauline leaves coriaceous blade, pinnatifid, with wide and blunt lobes, glabrous with very sparse stiff hairs along veins and margin; fruit with spheric distal joint, not acuminate ...

6. C. grandiflora

9. Leaves with non-divided blade, or lyrate-pinnatifid, cordate-ovate to elliptic-ovate; stamen filaments without teeth, except in C. hedgei

9. Leaves with pinnati-lobed or lyrate blade, sometimes not divided due to reduction of blade at terminal segment; stamen filaments with one or two teeth (C. gordjaginii) near the apex

10. Basal leaves lyrate-pinnatifid, with apical segment from oblong to suborbicular and 1(2) pairs of lateral segments . 11

10. Basal leaves not divided, widely elliptic

7c. C. edentula var. balchanica
11. Basal leaves coriaceous, sparsely haired, with blade margen not ruffed ..................... 7a. C. edentula var. edentula

11. Basal leaves crass, glabrous, with ruffed blade margin

7b. C. edentula var. glabrata

12. Plants somewhat hairy, never glaucous ..................... 13

12. Plants glabrous, frequently glaucous ........... 8. C. armena

13. Basal zone of stems and leaves covered in fasciculate hairs, grouped over tubercules, giving the appearance of stellate

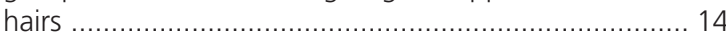

13. Basal zone of stems and leaves with non-grouped hairs ... 15

14. Velutinous plants; basal and inferior cauline leaves with apparently indivisive blade through reduction of terminal segment, glabrous sepals; fruit with proximal joint always sterile

9. C. alutacea

14. Plants with rough surface; basal and lower cauline leaves with lyrate blade, with terminal segment noticeably larger and separated from the sides; hairy sepals; fruit with proximal joint sometimes single-seeded ......... 10. C. shugnana

15. Yellow petals ........................................................ 16

15. White petals ...................................................... 17

16. Linear-spathulate petals, slightly narrowing towards the base, light-yellow colour ..................... 11. C. gordjaginii

16. Oblong petals, sharply narrowing towards the base, dark yellow colour .......... 12c. C. orientalis subsp. sulphurea

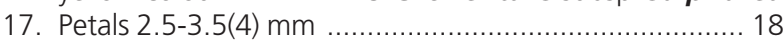

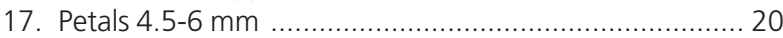

18. Basal leaves with ovate-elliptic blade, pinnatifid, with terminal segment similar in size and shape to sides ............. 19

18. Basal leaves with blade obovate, lyrate-pinnatifid, with terminal segment noticeably larger than the sides, sometimes the latter are absent

13. C. grossheimii

19. Branching axes of the inflorescence glabrous or rarely with sparse hair; fruit glabrous

12a. C. orientalis var. orientalis

19. Branching axes of the inflorescence densely pubescent; fruit with sparse antrorse hairs

12b. C. orientalis var. dasycarpa

20. Basal leaves with ovate-lanceolate blade, frequently pinnatolobed, covered with smooth whitish pubescence even in adults

14. C. hedgei

20. Basal leaves with ovate-elliptic blade, pinnatifid, pubescent when young, glabrous when adult .....

21. Leaves and base of stem glabrous or with very short, sparse hairs, even when young; upright pedicels, never adpressed; fruit with distal joint slightly rugose ..... 15. C. koktebelica

21. Leaves and base of stem densely haired, especially in young plants; adpressed pedicels, fruit with smooth distal joint ....

16. C. juncea

1a. Crambe cordifolia Steven in Mém. Soc. Imp. Naturalistes Moscou 3: 267. 1812 subsp. cordifolia (Fig. 1)

Type: RUSSIA. Stavropol. Georgievsk, 1835, D. Fischer 196 (isotypus LE!).

C. cordifolia var. microcarpa N. Busch in Kusn. \& al., Fl. Caucas. Crit. 3(4): 301. 1908

Type: S. T. Stepi bl. Karrasa. VII. fr. matur., Bietschtau. 1867 g. Obier.! fr. mat. Hohenakk. 4232, 4402 et sine n-o. (not seen).

C. cordata Willd., Enum Pl. Suppl.: 43. 1813, nom. inval. 
Hemicriptophyte, profusely branched from the base, $1-1.5 \mathrm{~m}$, lignified caudex up to $15-20 \mathrm{~cm}$ in diameter. Stem glabrous. Basal leaves bearing long petioles, with cordate, individed and irregularly serrated blade, of $10-15 \times 10-12 \mathrm{~cm}$, leaves on stem ovate or obovate, interrupted, the terminal segment with cordate base and 1-2 lateral segments. Glabrous sepals, of $2.5 \times 1.5 \mathrm{~mm}$, the middle ones oblong and the lateral oblong-ovate. White petals, of 4.5-5.5 $\times 2.5-3$ $\mathrm{mm}$, with oblong blade and ruffed margin, narrowed in a nail of 0.8-1 mm. Stamen filaments of $2.8-3 \mathrm{~mm}$ with the concave ventral face applied to the ovary with one subapical tooth, the sides shorter and without tooth. Fruit with very reduced and sterile proximal joint; distal joint globose, 4.5-5 $\mathrm{mm}$ in diameter, slightly strengthened at the edges.

Habitat and distribution. Native to the steppes and plains to the north of the Caucasus. Can be found spontaneous in the $S$ of Great Britain (Jalas \& al., 1996).

\section{Representative specimens}

AZERBAIJAN. Cáucaso septentrional: Kazakh, Richter s.n (BM). SPAIN. Madrid: Cult. Hort. E.T.S.I.A. U.P.M., ex sem. Bansem-U.P.M. 0511-64, 25-V-1998, A. Prina 1002 (MA).UNITED KINGDOM. Staffordshire: Wolwerhampton, waste ground alongside the Essington canal at Horsley Fields, 14-VI-1974, Price s.n. (BM).

1.b. Crambe cordifolia subsp. kotschyana (Boiss.) Jafri, Fl. West Pakistan 55:35. 1973 (Fig. 2)

C. kotschyana Boiss., Pl. Or. Diag. Ser. 1(6): 19. 1845 [basionym]

C. cordifolia Steven var. kotschyana (Boiss.) O.E. Schulz in Engler, Pflanzenreich 70: 236. 1919

Ind. loc.: "Hab. ad latera in occidentalia montis Sabst-Buschom prope Schiraz (Kotschy N ${ }^{\circ} 380$ )".

Type: IRAN. Fars, Mt. Sabst-Buschom, prope Schi- raz, 14-5-1842, Kotschy 380 (isotypes, BM!, E!, MPU!, LE!).

C. sewerzowii Regel, Bjull. Moskovsk Obsc. Isp. Prir., otd. Biol. 43(1): 282. 1870

C. cordifolia Steven var. kotschyana (Boiss.) O.E. Schulz subvar. sewerzowii (Regel) O.E. Schulz in Engler, Pflanzenreich 70: 236. 1919

Ind. loc.: "In Turkestaniae promontorio KcharliTau (Karatau) leg. Sewerzow, in deserto inter fluv. Syr-Darja et Taschkent, in fluvii Sarawschan satis frequens, inter Karakasuk et Schagimardan (O. Fedtschenko, Korolkow)”.

C. palmatifida Regel \& Schmalh. ex Regel, Trudy Imp. S.-Peterburgsk. Bot. Sada 5(1): 243. 1877

C. cordifolia Steven var. kotschyana (Boiss.) O.E. Schulz subvar. palmatifida (Regel \& Schmalh. ex Regel) O.E. Schulz in Engler, Pflanzenreich 70: 236. 1919

Ind. loc.: "In Turkestania, ad fluvium Ters in montibus Abraschan leg. Krause".

C. amabilis Butkov \& Majlun, Bot. Mater. Gerb. Inst. Bot. Acad. Nauk Uzbeksk. S.S.R. 17:3. 1962

Ind. loc.: "Gori Kartshantau. Okr. Leninska. Po darogie v Stepnoie, sklonii jalmov vsiudu. 1959.V.25 fl. Bondarenko O. H. i Butkov A. IA., 141" (Cyrillic in protologue).

Hemicriptophyte $1.5-2 \mathrm{~m}$, with a monopodial stem, branched in its terminal part with single stem and with intensely lignified basal region, with scattered hairs. Basal leaves 30-50 × 50-55 cm, bearing long petioles, cordate to sub-kidney shaped blade and lobed or serrate margin, cauline leaves subsessile, glabrous or with sparse hair. Sepals $4-4.5 \mathrm{~mm}$, all very similar, with stiff antrorse hairs on the back. Petals 6$7 \times 4-4.5 \mathrm{~mm}$, white, with oblong blade, narrowed to
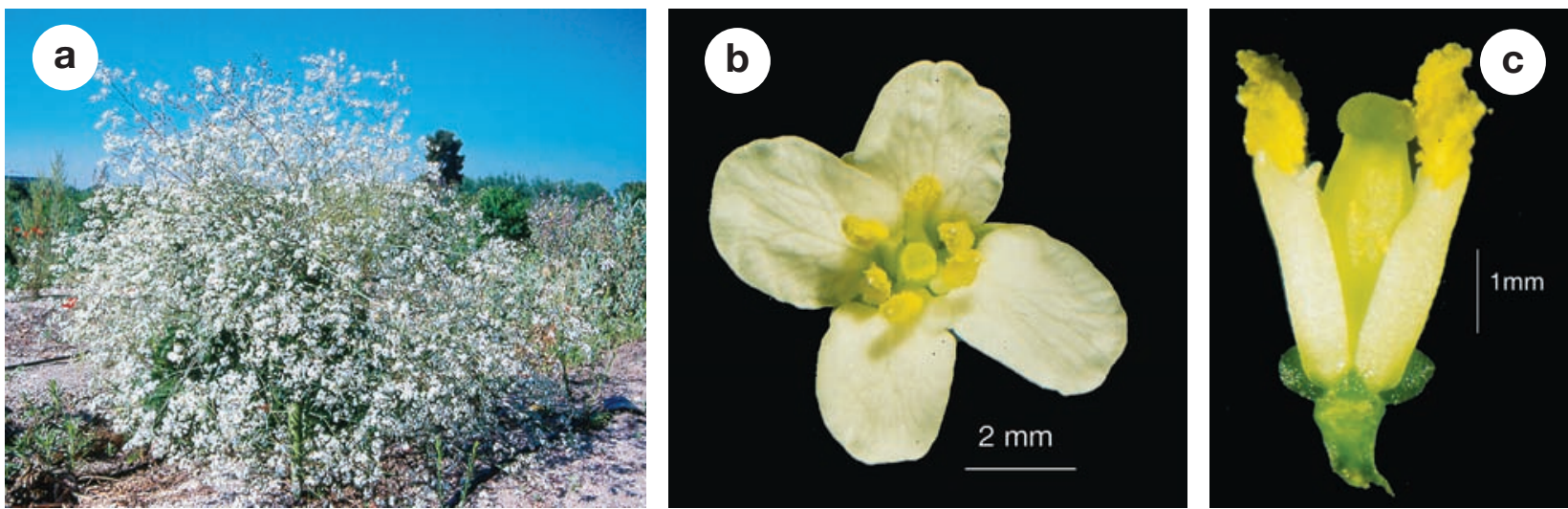

Fig. 1. Crambe cordifolia subsp. cordifolia. Grown at ETSIA-UPM: $\mathbf{a}$, plant in bloom; $\mathbf{b}$, flower from above; $\mathbf{c}$, flower without perianth. 
a nail of 0.3-0.4 mm. Stamen filaments with concave ventral face and one apical tooth of c. $0.5 \mathrm{~mm}$. Fruit with proximal joint stipitate and the distal joint globose, of 4-6.5 $\mathrm{mm}$ in diameter, four strengthened edges, reticulate surface, single-seeded.

Habitat and distribution. Rocky hills and steppes between 500 and $2000 \mathrm{~m}$ in Central Asia and NW India.

\section{Representative specimens}

AFGHANISTAN. Katagahn: Farqar upper valley, 7 milles of Farqar, 8000 ft. 29-VI-1966, P. Furse 8184 (E). INDIA. Himachal Pradesh: Chandrabhaga valley, Pangi Raoli, 8000 ft., 20-V-1976, Stainton 7574 (BM). IRAN. Fars: Estahbanat, $65 \mathrm{~km}$ from Shiraz, Tange Jahal mountains, 1600-2600 m, 19-V-1975, Moussavi \& Teberani (EVIN 14710). PAKISTAN: Baluchistan: Urak, Puchta, 7500 ft., 30-IV-1888, J.H. Lace 3751 (E). Tayikistán: North Mount. Sari-Sait, 28-VI-1962, Filatova 91 (LE). TURKMENISTAN. Balkanskiy Velayat: Kisil Arwat, Kara-Kala, in monte Sunsodagh, 18-V-1901, P. Sintenis 1761 (BM). UZBEKISTAN. Samarqand Wiloyati: Samarkanda, 16-VI-1968, Dudshiski s.n. (LE).

The subordination of this entity to C. cordifolia is

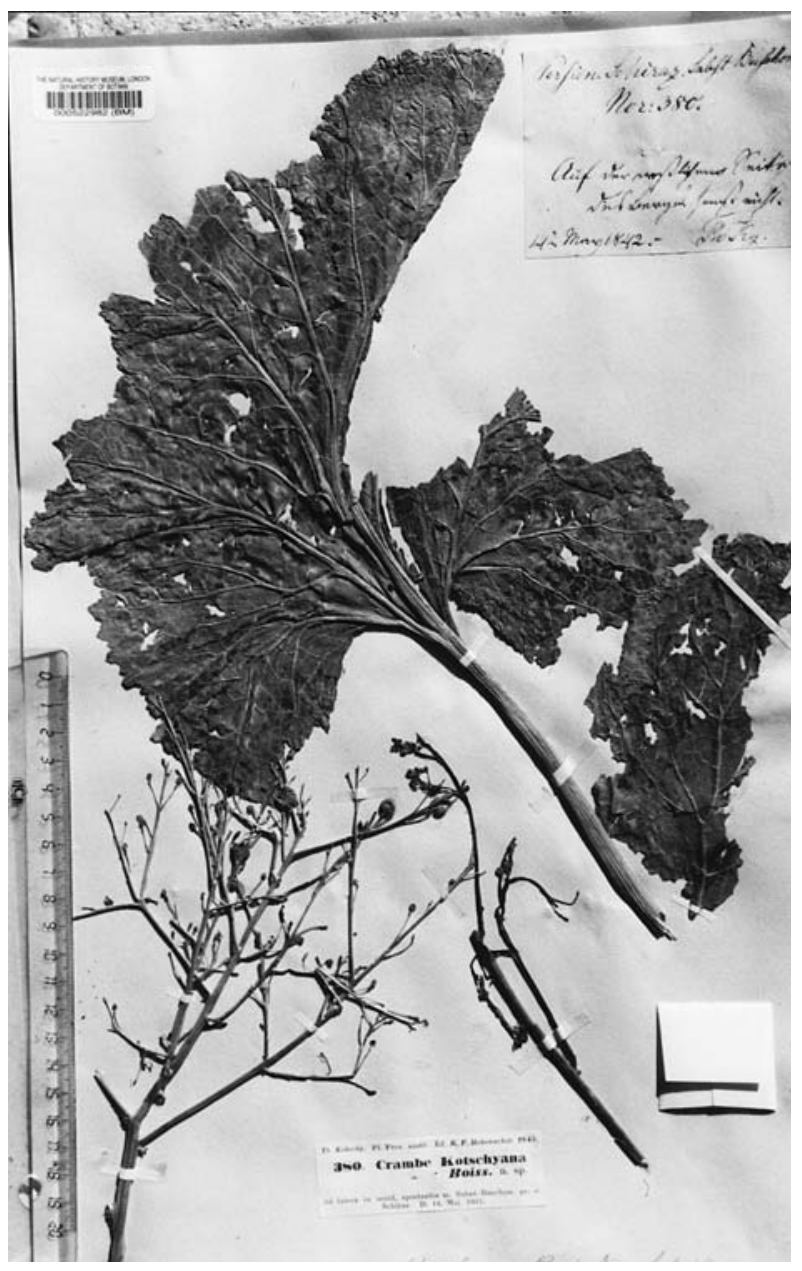

Fig. 2. Crambe cordifolia subsp. kotschyana. Type, Kotschy 380 (isotype BM). based solely on the difference of greater thickness and less hairiness of the leaves and that its fruit is somewhat smaller. Jafri (1973) states that some specimens from the region of Baluchistan show intermediary characters, which has been confirmed in the study of the specimen J. H. Lace 3751. Boissier himself, in the protologue of C. kotschyana, points to its affinity with C. cordifolia and only points to differences of little significance and great variance such as the size of the flowers and the degree of pubescence. Hedge (1968), while assigning it a specific rank, recognizes this affinity and the little relevance of the characters that differentiate them. Furthermore, both taxa have a different geographic distribution. The specimens with less hair, with flowers and fruit of greater size and leaves less profoundly divided, which are here designated to the subsp. kotschyana, are distributed around the eastern region of Iran and S of Afghanistan to Pakistan and to India, whereas those of smaller size, in general with more profoundly divided leaves and more densely-haired, corresponding to the subsp. cordifolia, are limited to the region $\mathrm{N}$ of the Caucasus.

2. Crambe maritima L., Sp. Pl. 1: 671.1753 (Fig. 3) Cochlearia maritima (L.) Crantz, Class. Cruciform. emend.: 96. 1769

Caulis maritimus (L.) E.H.L. Krause, Bot. Centralbl. 81(6): 207.1900

Crucifera maritima (L.) E.H.L. Krause in Sturm, Fl. Deutschl. 2(4): 126. 1902

Ind. loc.: "Hábitat ad littora Oceani Septentrionalis".

Type: Herb. Clifford: 340, Crambe No. 1 (photo lectotypus BM !) (designated by Hedge, 1993).

Crambe pontica Steven ex Rupr., Fl. Cauc.: 293. 1869, nom. nud.

C. maritima L. prole pontica (Steven ex Rupr.) O.E. Schulz in Engler, Pflanzenreich 70: 231. 1919

Ind. loc.: "Mediterrangebiet.- Mittlere Mediterranprovinz in der euxinischen Zone".

C. gigantea Kitaibel ex Janka, Oestr. Bot. Zeitschr. 21: 65. 1871, non Bramwell (1969)

Ind. loc.: "Habitat in Dalmatia. Floret Junio. Quinto a stattione anno. Flores mel redolent".

Glabrous chamaephytes or hemicriptophytes, with gemmiferous roots and with lignified caudex of 3-6(8) $\mathrm{cm}$ in diameter, from which issue numerous aerial stems. Basal and lower stem leaves with petiole of 2-3 $\mathrm{cm}$, short crass, canaliculate, and glaucous petioles, blade $14-40 \times 7-30 \mathrm{~cm}$, oblong-elliptic, from irregular- 
ly pinnatifid to pinnatisect, with ruffed margin, irregularly serrated and overlapping lateral lobes, smaller upper stem leaves, oblong-elliptic and generally sessile. Sepals subequal, glabrous. Petals 7-9 mm, white, blade widely oblong, sometimes slightly cleft at apex. Staminal filaments two times serrated, with concave side applied to ovary and forming an apparent staminoid tube. Fruit with proximal joint cylindrical, 0.5$0.8 \mathrm{~mm}$; distal 6-10 mm, globose, single-seeded, corktextured when mature and irregularly rugose surface.

Habitat and distribution. Disjunct distribution, on the coasts of the Northern Sea and the Baltic Sea, from France to Finland, spreading towards Eastern Europe, probably through cultivation, and on the coasts of the Black Sea, in the region of Crimea. Grown as a vegetable in the Caucasus region (Czerniakowskaya, 1939). The fruit is adapted to hydrocory (Scott \& Randall, 1958).

\section{Representative specimens}

DENMARK. Grena: NW of Grena at sea level in pebbles along the coast, 21-VI-1986, K. E S. Larsen 40081 (MA, MAF). ESTONIA. Saaremaa 14-IX-1966, Leonova $\varepsilon$ al. "a” (LE). FINLAND. Turunporin Lääni: Korpo, Aspö, Vdskär, 11-VII-1920, O. Eklund 1201 (LE). FRANCE. Bretagne: Cotes de Bretagne, I-1845, sin colector (MA 147416). GERMANY. (MA 147415). NORWAY: Uppland, Paroecia Djüro, Horssten, in litore glareoso, 8-VIII1926, Sammuelson E Zanders 860 (LE). UNITED KINGDOM. Sussex: Atherington, 5-VI-1973, Wurzell s.n. (VIR, MO). ROMANIA. Dobrogea: bieriegu Chernoie More (Cyrillic: coast of the Black Sea), 22-V-1958, Moravich s.n. (LE). RUSSIA. Rostov: ca. Margaritovsk, 29-VIII-195?, Sarandinaki (LE). SWEDEN. Göteborgs: Bahusia, N.J. Anderson (MA 147565). UKRAINE. Na siebero bieregu Chernoie More (Cyrillic: N coast of the Black Sea), 22-V-1948, Pobedimova 300 (LE).

The materials from the Black Sea have been considered by Schulz (1919), among others, as a different taxon, be this as a species under the denomination
Crambe pontica Stev. ex Rupr. or with this species name in a rank subordinate to C. maritima. No differentiating morphological traits have been found between samples from one region or the other, for which reason we consider it convenient to keep all this material under the same species without acknowledging intraspecific taxa.

There has been one citation for the coast of the Dead Sea; however, according to Dinsmore (1932) this must be an erroneous citation, possibly confusing it with Cakile maritima L. Schulz (1919) points to the same mistake in older citations of the species on the coast of the Mediterranean. The possible occurrence of this species on the coast of Galicia (Spain), cited by Planellas (1852), although without mentioning the herbarium voucher, is more that questionable.

3. Crambe pinnatifida R. Br. in W.T. Aiton, Hort. Kew 2 ed., 4: 72. 1812

C. tataria Sebeók var. pinnatifida (R. Br.) O.E. Schulz in Engler, Pflanzenreich 70: 235. 1919

C. orientalis Jacq., Ic. Pl. Rar. 1, ed. 2: tab. 128. 1781, non L. (1753)

C. orientalis sensu M. Bieb. Fl. Taur.-Cauc. 2: 89. 1808, non L. (1753)

Ind. loc.: "Nat. of Siberia", "Cult. before 1759, by Mr. PH. Miller. Mill. dict. ed. 7. Crambe 2”.

Hemicriptophyte, $50-90 \mathrm{~cm}$, entirely glabrous. Petioled basal leaves, with blade 17-30 × 23-26 cm, ovate-elliptical, pinnatifid, pinnatisect or pinnatipartite, sinuate-serrate margin, oblong lateral segments and terminal oblanceolate, with stem leaves similar although of smaller size. Oblong sepals, glabrous. Petals 4-4.5 mm, white with obovate blade, sharply narrowing to a nail of $0.2-0.3 \mathrm{~mm}$. Staminal filaments
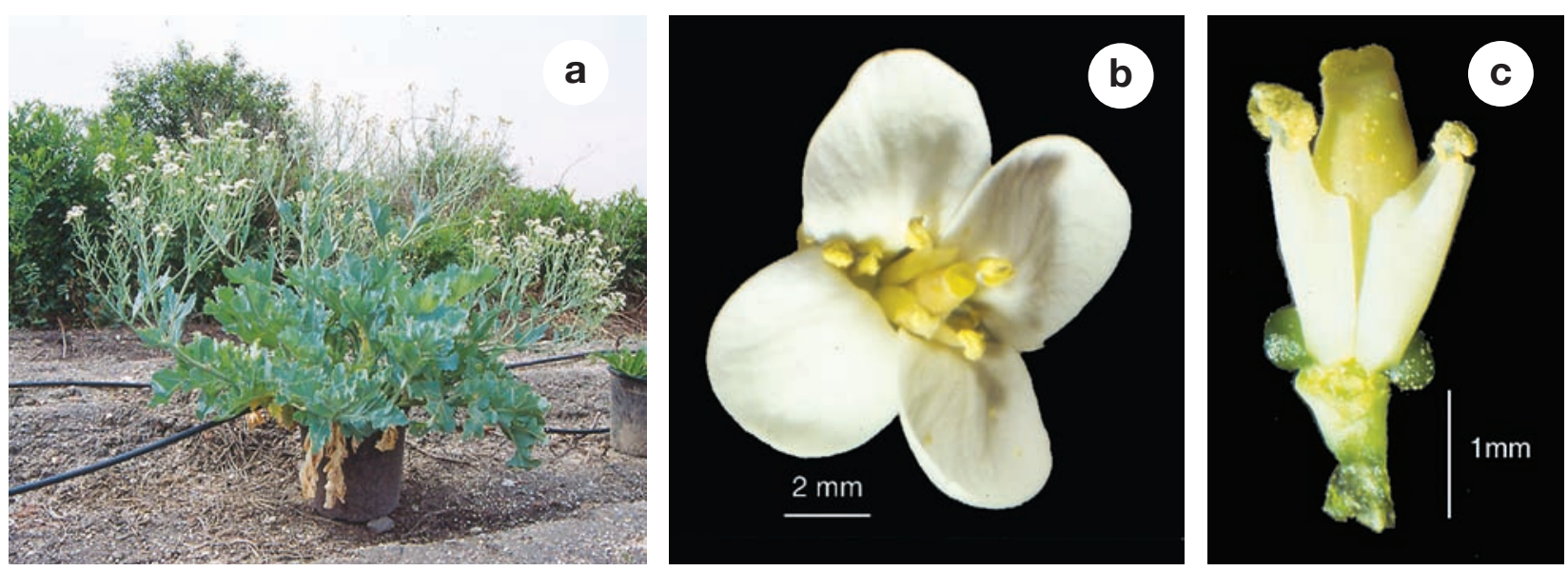

Fig. 3. Crambe maritima. Grown at ETSIA-UPM: a, plant in bloom; b, flower from above; c, flower without perianth. 
with one subapical tooth of $0.2-0.3 \mathrm{~mm}$. Fruit with proximal joint obconic and sterile, and distal joint spherical, of 5.5-6 mm in diameter, smooth or slightly rugose, single-seeded.

Habitat and distribution. steppes and hills rich in clay in Eastern Europe as far as Armenia.

\section{Representative specimens}

ARMENIA. In Tauria et am Caucasus, Pallas s.n. (BM). ROMANIA. Iasi, Valea lui David, 20-V-1967, M. Toma 148 (BM). UKRAINE. Berdjanska kosa, 14-IX-1990, Levichev \& Muravchenko 779 (BM).

4. Crambe tataria Sebeók, Diss. med.-bot. de Tataria hung.: 7.1779

Ind. loc.: "Circa Agriam Hungaria, Eger".

Type: W (not seen).

\section{4a. C. tataria Sebeók var. tataria}

C. laciniata Lam., Encycl. 2: 163. 1786

Ind. loc.: "3. Crambe lacinié, Crambe foliis subbipinatis, pinnis laciniatis dentatis subtus scabris, caule laevi ramosissimo. N.".

C. pannonica Hort. ap. Lam., Encycl. 2: 163.1786

Ind. loc.: "H. R. Crambe (Tataria), foliis decomposito multifidis".

C. orientalis Falk, Beirtr. Russ. Reich. 2(14): 219. 1786, non L. (1753)

Ind. loc.: "Russ. Katran... In der Rumanischen und Kalmukischen Steppe...”.

C. tatarica Pall. in Güldenstädt, Reis. Russ. 1: 194. 1787, nom. nud.

C. caspica Raeuschel, Nom. 3 ed.: 183. 1797 (cf. Schulz, 1919)

C. tataria Sebeók var. bungarica DC., Syst. Nat. 2: 653. 1821. "Foliorum caulinorum lobis oblongolinearibus subintegris subpectinatis".

C. tataria Sebeók var. taurica DC. Syst. Nat. 2: 653. 1821. "Foliorum lobis oblongis sinuatis lobatis".

C. biebersteinii Janka, Termeszetud. Füz. 8: 36. 1884

C. tataria Sebeók var. biebersteinii (Janka) O.E. Schulz in Engler, Pflanzenreich 70: 234. 1919

Type: UKRAINE. Ex Tauria, Steven 1815 (LE!).

C. macro- vel chlorocarpa vel laevis Kittaibel ex Kanitz, Linnaea 22: 502. 1863

Ind. loc.: "Habitat in aggeribus Syrmii et pratis Cottus Csanadensis”.

C. putaria Radde, Kauk. Mus. 2: 58. 1901 (cf. Schulz, 1919)
Hemicriptophyte, with a single upright stem of 30$70(120) \mathrm{cm}$, profusely branched in the upper part. Subcrass basal leaves, grey-green in colour, with highly canaliculate petiole broadening at base, blade of proximal leaves individed, margin serrate in diverse ways, the next leaves highly pinnatipartite, more distal leaves 1-2(3) times pinnatifid to pinnatipartite, with blade of 30-35 $\times 25-30 \mathrm{~cm}$, with abundant stiff hairs on the margin and the veins, especially in young plants. Sepals 2-2.5 mm, oblong, white margin, rarely with occasional hairs in the abaxial face. Petals 4.5-5 $\mathrm{mm}$, white, with blade broadly oblong-ovate, subtruncate in the apex, sharply narrowing to a nail. Staminal filaments with one subapical tooth, anthers frequently violaceaous. Fruit with proximal joint obconic, $0.3-0.4 \mathrm{~mm}$ and sterile, the distal joint sub-globose $4-5(7) \mathrm{mm}$ in diameter, noticeably tetragonous and with conspicuous veins, single-seeded.

Habitat and distribution. It grows on steppes and hills rich in clay and limestone from Eastern Europe to the Caucasus. The adult plant usually breaks up at the base and thus becomes an organ of dispersal (tumbleweed).

\section{Representative specimens}

AUSTRIA. Niederösterreich: Ottenthal prope Staatz, 13-V1928, Rechinger (BM). CZECH REPUBLIC. Jihomoravský: Moravia australis, Spidlack prope opp. Cejc, 30-VI-1939, Mylos Deyl (LE). HUNGARY. Vezprém: Balatonkenese, Balaton karattya, 18-VII-1932, E. Gossleth s.n. (LE). ROMANIA. Sibiu: Transilvania centralis, 16-V-1808, Janka s.n. (BM). RUSSIA. Saratov, Stepa am Ingun, Volgum, Rebman 18 (BM). SERBIA. Vojvodina: Banatus ad Grebenacz, 1835, Heuffel 25 (BM, LE). TURKEY. Çankiri: Kalecik, 9-VI-1951, Davis 21761 (BM, E).

4b. C. tataria var. aspera (M. Bieb.) Boiss., Fl. Or. 1: 406. 1867

C. aspera M. Bieb., Fl. Taur.-Cauc. 2: 90. 1808 [basionym]

Ind. loc.: "Hábitat in deserto Caucasico-Caspico et ad Wolgam inferiorem".

Type: RUSSIA. Dagestan, 1781, Jacquin (BM!).

C. litwinowii Gross., Feddes Repert. Spec. Nov. Regni Veg. 23: 397. 1927, in syn. Crambe gibberosa Rupr., Mem. Acad. Sci. St. Petersbourg 7(15-2): 136. 1869

Type: RUSSIA. Dagestan, Mt. Beschbarmak, 21-71830, without collector, Enum. Cauc. Casp. 1694 (LE!).

C. tataria Sebeók var. buschii O.E. Schulz in Engler, Pflanzenreich 70: 234. 1919

C. buschii (O.E. Schulz) Grossheim, Fl. Kavkaza 2: 179. 1930 
Ind. loc.: "Krim, Ciskaukasien, und Daghestan: an etwas salzhaltigen Stellen (nach Busch)".

Glaucous plants up to $40 \mathrm{~cm}$, densely hispid in leaves and stems, even in adult plants. Stem leaves highly pinnitipartite with lobes generally narrower than in the typical variety.

\section{Representative specimens}

FRANCE. Hérault: Montpellier, Cult. Hort. Monsp. ex sem. Sarepta, 23-IV-1834, Herb. Fac. Mèdecine 396 (MPU). HUNGARY. Somogy: in pratis Szenafü prope opp. Kaposvar, 23-VI1876, Barth 1534 (LE). KAZAKHSTAN. Aqtobe: Akt'ubinsk, 12 VI-1965, Tscherkasova s.n. (LE). RUSSIA. Saratov (Sarepta): Volga, Pallas fol. 6 (BM, MA). TURKEY. Maras: Elbistan, 1200 m, 8V-1957, Davis \& Hedge 27687 (E, K).

It has been considered endemism in the region of the Lower Volga and the desertic area between the Caucasus and the Caspian Sea (Czerniakowskaya, 1939); however samples have been studied that were gathered in Turkey and Hungary whose characters correspond to those of this variety, thus considerably extending its area of distribution.

The differentiating morphological characters do not justify species status, nor present a differential area of distribution, for which reason we confirm its status as a variety, following Boissier.

Ruprecht (1869) describes C. gibberosa claiming an alledged tuberculate surface of its fruit. The type specimen has been studied and these "tubercules" are simply surface wrinkles due to the immature state of these fruits; all other characters coincide with those of the variety aspera.

5. Crambe steveniana Rupr., Mem. Acad. Sci. Saint Petersbourg 7(15-2): 136. 1869

Ind. loc.: "Distinguatur talem plantam vidi in herb. Meyeri e campis ciscaucasicis pr. Georgieffsk (Höfft!), fructiferam foliis glaberrimis...”.

Type: RUSSIA. Stavropol, Georgievsk, V. Höfft (4 samples isotypes, LE!).

C. steveniana Rupr. f. oxycarpa Rupr. Mem. Acad. Sci. Saint Petersbourg 7(15-2): 136. 1869

Ind. loc.: "...datur etiam hujus forma oxycarpa....., in hortis culta por C. grandiflora (Herb Ledebour)".

C. pinnatifida Steven, Verzeichn. Pfl. Taur. Halbins.: 290. 1856, non R. Br. (1812) (cf. Schulz, 1919)

Hemicriptophyte, glabrous and glaucous green in colour, $60-100 \mathrm{~cm}$. Basal leaves with petioles, blade $18-30 \times 14-30 \mathrm{~cm}$, obovate, pinnitipartite, irregularly serrate with 2-3 lateral segments widely ovate, or two times pinnatipartite with narrow and sharp lobes; caulinar leaves also with petioles, blade oblong-lanceolate, margin whole or finely serrate. Sepals $2-3 \times$ c. 2 $\mathrm{mm}$, obtuse, glabrous. Petals 5-4.5 $\times 4 \mathrm{~mm}$ with obovate blade, gradually narrowing in a short nail, white. Staminal filaments with subapical tooth. Fruit with proximal joint cylindrical, very reduced, the distal joint ovoid, tetragonous and rugose, of 6-7 $\times 5-6 \mathrm{~mm}$, noticeably attenuate towards the apex when mature.

Habitat and distribution. Steppes and clay hills in the region of Crimea and $\mathrm{S}$ of the Caucasus.

Rarely collected, only type specimen studied. Czerniakowskaya (1939) recognises f. oxycarpa, and brings it up to the rank of variety on the basis of the acuminate fruits at both ends. Only one of the isotypes examined contains a sheath with several mature fruit which possess this trait, which however is not present in the fruits still attached to the specimen, for which reason the identity of this sample remains doubtful. As other samples with these traits have not been found and the remaining isotypes were in a very bad state of conservation, we felt it convenient to follow Schulz (1919), who does not recognize this variety. Curiously the fruit of this species is extremely similar to several Macaronesian species of sect. Dendrocrambe, especially in their acuminate and rugose distal joint, although the size of the fruit of $C$. steveniana is considerably larger.

6. Crambe grandiflora DC., Syst. Nat. 2: 652. 1821

Ind. loc.: "Hab. in insula Taman ad ostia anticetae (Kuban) ad Pontum Euxinum (Steven)"

Type: UKRAINE. Crimea, Península de Tamán, $M$. Bieberstein ex herb. Ledeb. 5772.2 (LE!).

\section{C. lipskii Czerniak. in herb.}

Type: UKRAINE. Inter Feodosia et Salia, litus meridion Koktebell, 10-5-1905, N. A. Busch Iter Tauricum I (LE!).

Branched hemicriptophyte of $60-100 \mathrm{~cm}$, stems with strengthened edges, glabrous or with sparse retrorse and patent hairs. Glabrous basal leaves or with very sparse stiff cilia along the veins and margin, blade ovate or ovate-lanceolate, highly pinnatipartite, with 4-6 lateral segments oblong to lanceolate, markedly sinuate-serrate to highly pinnatipartite, the caulinar leaves oblong, serrate, the distal leaves sublinear, generally whole. Sepals 3.4-4 mm, oblong. Petals (5)-5.5-6 × 3-4 mm, white, with oblong blade sharply narrowing to a nail. Staminal filaments of 3.5$4 \mathrm{~mm}$, with one tooth in the apical area. Fruit with proximal joint obconical $3.5-4 \mathrm{~mm}$, the distal joint 
tetragonous spherical or barely ovoid, of $7-8 \mathrm{~mm}$ in diameter, clearly veined and rugose.

Habitat and distribution. Known on the Taman peninsula and the estuary of the Kuban river in the Russian region of Krasnodar and in the region of Dagestan, its area now spreads considerably towards the $S$, including Turkey and Iran.

\section{Representative specimens}

IRAN. Teheran: Karadj to Chabous, Chalivard, 8-VIII-1966, Zargani s.n. (EVIN 14719/2). TURKEY. Biredjik: Hasehnadi, 1118-IV-1889, P. Sintenis 400 (E, W). UKRAINE. Karasubasar, in regione deserta et inculta, 23-V-1900, A. Callier 531 (LE).

In accordance with Schulz (1919), C. grandiflora is close to C. tataria. While the fruit with four strengthened and somewhat rugose edges remind us of the fruits of the latter, the rest of the plant is morphologically more similar to C. koktebelica and C. orientalis, especially in certain glabrous forms of this last species. The greater size of the flowers and in general of the fruit, however, indicate the convenience of keeping this taxon.

We have been able to study the 8 vouchers collected by N.A. Busch and determined by Czerniakowskaya to be C. lipskii Czerniak. On one of these, in the handwriting of that author, the word typus is accompanied by a brief description and a drawing in pencil of a petal, preliminary elements of a diagnosis which however would seem not to have been published. From the study of this material and their comparison with the type specimen of $C$. grandiflora DC. we deduce that we are dealing with the same taxonomical entity.

7. Crambe edentula Fisch. \& C.A. Mey. ex Korsh., Bull. Acad. Imp. Sci. Saint Petersbourg 5(9-5): 421-422. 1898

Ind. loc.: "In Turcomania boreali a Karelin detecta". Type: TURKMENISTAN. Novo Krasnowodsk, ad Mare Caspio, Karelin (isotype, LE!).

Three varieties are distinguished and are differentiated by the following characters.

\section{7a. C. edentula var. edentula (Fig. 4)}

Chamaephyte of $45-70 \mathrm{~cm}$, with thin root, lightly lignified, and stems with multiple strengthened edges, with leaves at proximal end. Basal and proximal cauline leaves with stiff hairs, especially along the veins and in the petiole, blade $4-12 \times 4-10 \mathrm{~cm}$, lyratepinnatifid, with 1 terminal segment ovate-cordate, distal caulines linear-subulate, subsessile or with short petiole, of 2-3.5 cm. Sepals $2.8-3 \mathrm{~mm}$, oblong, subequal, glabrous. Petals 4.5-6 $\times 2.5-3 \mathrm{~mm}$, white, with blade oblong-obovate. Staminal filaments $2.3 \mathrm{~mm}$, with no apical tooth and with small wings. Fruit with proximal joint $0.5-0.8 \mathrm{~mm}$, distal joint widely ovate to sub-spherical 3.5-4 $\mathrm{mm}$ in diameter, glaucous, with smooth surface, with a viable seed and, sometimes, also vestiges of an accompanying seed.

Habitat and distribution. Rocky slopes, holes and fissures in the $\mathrm{N}$ of the Caucasus and gypsum and limestone soils on the coast of the Caspian Sea.

\section{Representative specimens}

TURKMENISTAN. Ajalskiy Velayat: Kopet Dag, 60 km Aksadag, 8-V-1963, Gubanov 163 (LE).

Although this presents morphological similarities to C. kralikii Coss. and C. hispanica L., both of which belong to sect. Leptocrambe, the scarce development in length of the proximal joint leaves little doubt that it should be included in the section Crambe.

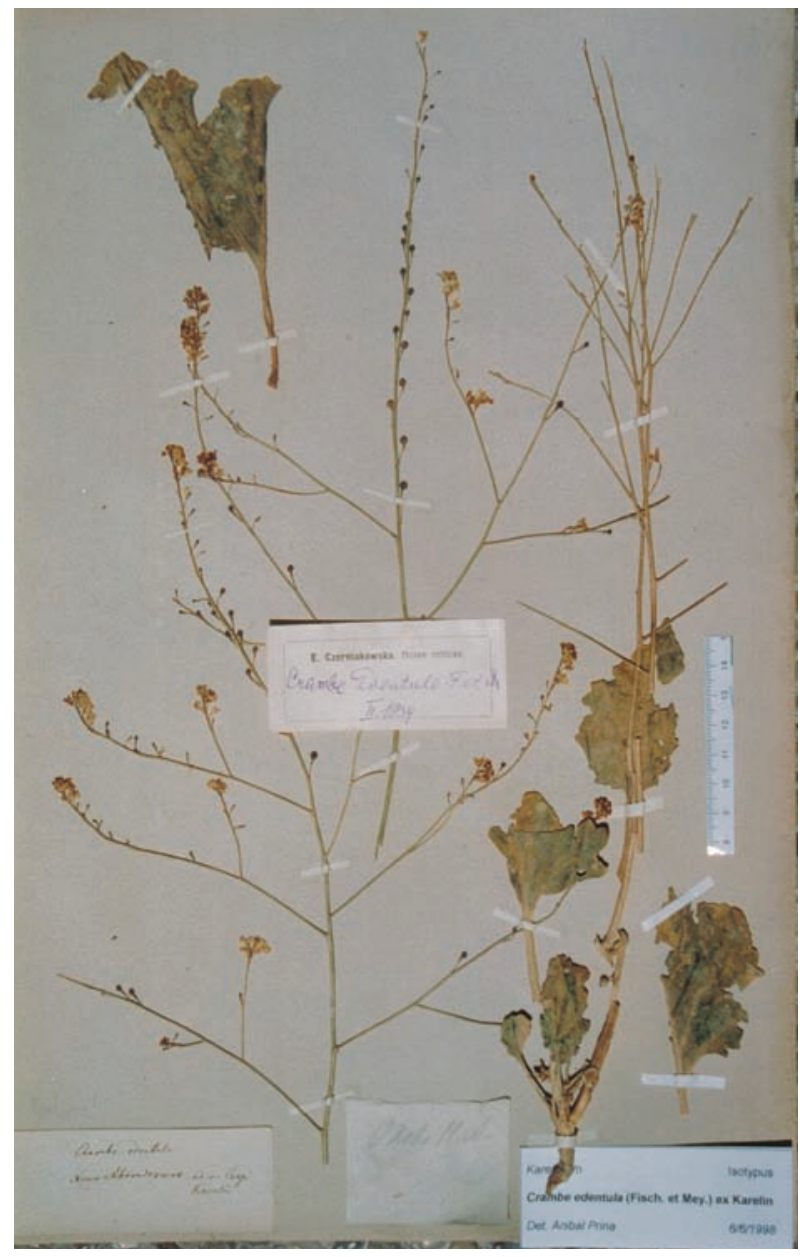

Fig. 4. Crambe edentula subsp. edentula. Type, Karelin s.n. (isotype LE). 
7b. C. edentula var. glabrata (Freyn \& Sintenis) Prina, comb. nov. (Fig 5)

C. juncea M. Bieb. b glabrata Freyn \& Sintenis in Freyn, Bull. herb. Boiss. 3, ser. 2(34): 858. 1903 [basionym]

Ind. loc.: "Krasnowodsk, in deserto arenoso pr. Ufra. 24.IV.1901. In Knospen mit der ersten sich entfaltenden Blüthe”.

Type: TURKMENISTAN. Balkanskiy Velayat, Krasnowodsk, in deserto arenoso prope Ufra, 24-41901, P. Sintenis 1581 (WU!).

C. edentula Fisch. \& Mey. ex Korsh. var. cretacea Czerniak., Izv. Glavn. Bot. Sada S.S.S.R. 24: 120. 1925

C. cretacea (Czerniak.) Czerniak., Izvn. Glavn. Bot. Sada S.S.S.R. 28: 397-398. 1929

C. edentula Fisch. \& Mey. ex Korsh. var. freynii Czerniak., Fl. URSS 8: 487. 1939, nom. illeg. in textu

Further to the differences noted in the key, it differs

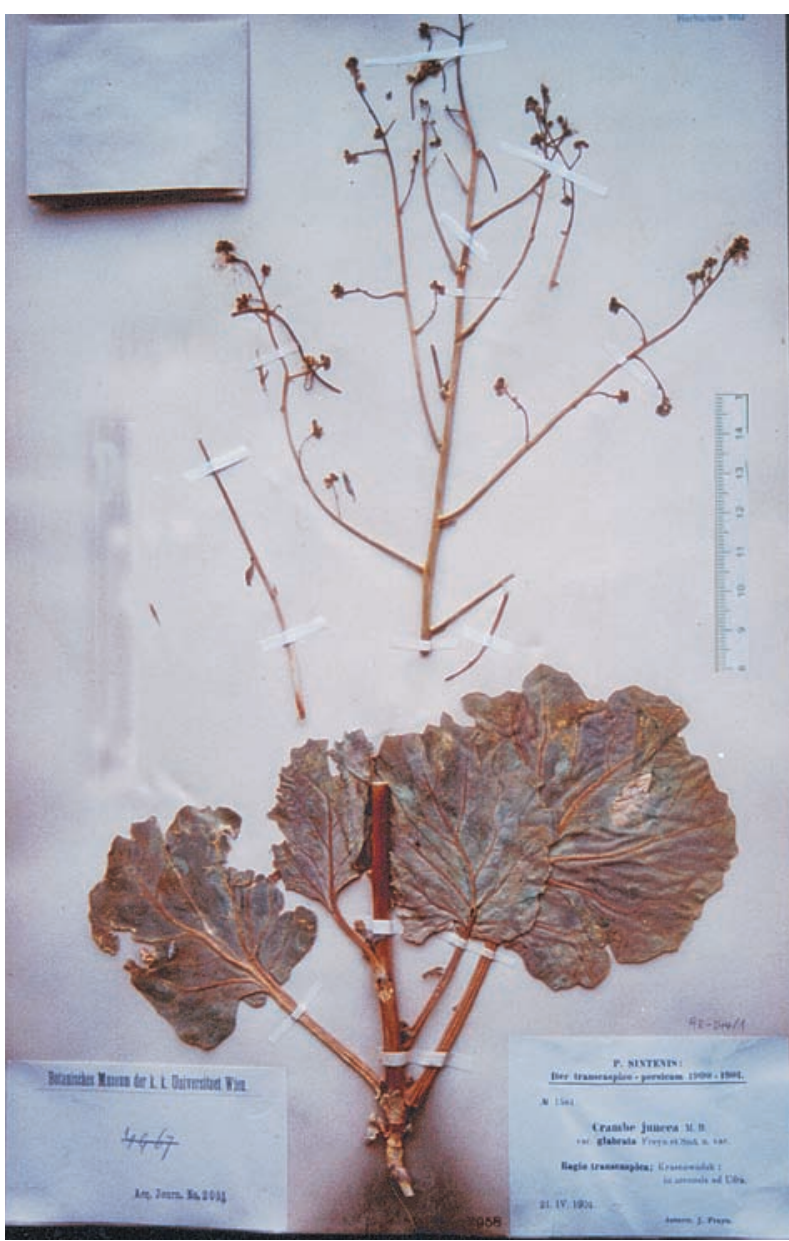

Fig. 5. Crambe edentula subsp. glabrata. Type, P. Sintenis 1581 (WU). from the typical variety in the greater size of its flower. The sample studied did not have fruit.

Habitat and distribution. Shares area with typical variety.

\section{Representative specimens}

Only type specimen was studied.

Czerniakowskaya (1925) describes C. edentula var. cretacea and later (Czerniakowskaya, 1929) raises it to the rank of species. Among the several samples studied therein, the first to be cited is the sample Sintenis 1581, which had been used to describe $C$. juncea $\mathrm{b}$ glabrata (Freyn, 1903). Later, Czerniakowskaya (1939) omits any allusion of the species name cretacea but undertakes a critical analysis of the sample Sintenis 1581 and on this basis proposes C. edentula var. freynii Czerniak., which is an illegitimate name, since in the varietal range, the epithet used by Freyn $\&$ Sintenis holds priority. These authors seem to have been unconvinced of the systematic position of their variety, noting that the absence of teeth on the stamen distanced it from $C$. juncea, but the indicated no affinity with C. edentula.

7c. C. edentula var. balchanica Czerniak. in V.L. Komarov, Fl. URSS 8: 486. 1939

Type: TURKMENISTAN. Balkanskiy Velayat, Balchan, 900 m, 25-5-1928, Jarmolenko \& Fedtschenko 153 (lectotype LE, here selected).

Distinct from the typical variety in its crass leaves at the base, with petioles of $5-8 \mathrm{~cm}$, slightly widening at base and blade 10-12 ×9-10 cm, widely ovate and reduced at terminal segment, with sinuate-serrate margin with adpressed and rough hairs.

Habitat and distribution. Grows in the region of the Balkhan range (Turkmenistan) and in the surroundings of the eastern coast of the Caspian Sea.

The specimen Jarmolenko E Fedchenko 153 (LE) possesses a label which identifies with the name of this variety, written in Czerniakowskaya's hand, we therefore propose that it here be considered its lectotype.

8. Crambe armena N. Busch, Monit. Jard. Bot. Tiflis nouv. ser., 3-4: 7-8 (1927).

Type: AZERBAIJAN. Nachicevan, prope salinas, 12-5-1923, Grossheim (LE!).

Hemicriptophyte of 50-60 cm; glabrous plants, frequently glaucous. Basal leaves with petiole of $2-2.5 \mathrm{~cm}$, blade 7-10 $\times 4-5 \mathrm{~cm}$, from individed to lyrate or pin- 
natilobed, at times reduced at terminal segment, with ruffed margin, caulines sessile, blade oblong 3-4 × 2 $3.5 \mathrm{~cm}$, margin irregularly serrate. Sepals $2 \mathrm{~mm}$, oblong. Petals white, with blade $3.5-4 \mathrm{~mm}$, elliptical, sharply narrowing in one nail $0.2-0.3 \mathrm{~mm}$. Staminal filaments with one apical tooth. Fruit with proximal joint cylindrical 1-1.5 mm, sterile; the distal joint globose, smooth, of $3.5 \mathrm{~mm}$ in diameter, with a single seed.

Habitat and distribution. Grows in salty soils in the region of the Caucasus and to $\mathrm{W}$ of Turkmenistan, form which it was cited for the first time.

\section{Representative specimens}

TURKMENISTAN. Balkanskiy Velayat: Krasnowodsk, Kazanzikskii, ca. Danata, 25-5-1955, Lukmanov \& Nikitin (VIR 46466B, pro parte).

9. Crambe alutacea Hand.-Mazz., Annal. K. K. Naturhist. Hoffmus. 27(1):53. 1913 (Fig. 6)

C. orientalis L. var. alutacea (Hand.-Mazz.) Hedge \& Hub.-Mor., Notes Roy. Bot. Gard. Edinburgh 26: 181. 1965

Ind. loc.: "In steinigen Kalksteppen am Nordfuss des Dschebel Abd el Asis zwischen el Abed und Gharra, 21.IV (Nr. 1709) und zwischen Gharra und Spaijan 23.IV.1910 (Nr. 1822), auf Mergel bei Gharra. Dann (nur nach Notizen!) auf der Hochfläche zwischen Urfa und südlichen Kette des Taurus gegen Kjachta auf steinigen Stellen und von Schios nördlich von Mossul gegen Peschawur, 400-800 m”.

Type: SIRIA. Al-Hasakah, Nordfuss des Dschebel Abd el Asis zwischen el Abed und Gharra, 21-4-1910, Hand.-Mazz. 1709 (isosintype, W!); zwischen Gharra und Spaijan 23-IV-1910 Hand.-Mazz. 1822 (isosintype, W!).

Hemicriptophyte with gemmiferous roots, of 80$100 \mathrm{~cm}$., velutinous plant. Basal leaves with canaliculate petiole of $2.5-5 \mathrm{~cm}$, blade elliptical-lanceolate, apparently individed or pinnatifid, with 4-8 lateral segments obovate and terminal segment similar to laterals and converging with these, subcrass, colour green-greyish, densely covered by hairs arranged in tubercules, the caulines sparse, sessile, poorly pubescent. Sepals oblong, white edged, glabrous. Petals yellow, with blade oblong of c. $3 \times 1 \mathrm{~mm}$, sharply narrowing in a nail of $0.3-0.4 \mathrm{~mm}$. Staminal filament with a hardly perceptible apical tooth. Fruit with proximal joint obconical, irregularly striated-rugose; the distal joint spherical, of 3-3.5 mm in diameter, smooth or finely reticulate to verrucose, single-seeded.

Habitat and distribution. Grows in arid and desert areas, in limestone steppes of $\mathrm{N}$ of Syria, Iraq and SE Turkey (Prina, 1998).

\section{Representative specimens}

IRAQ. Ninawá: $40 \mathrm{~km}$ from Shabahiyah to Sinjar, 1400 m, 4-41978, Al Kaisi \& Hamad 48989 (K). TURKEY. Gaziantep: AinTab (Gaziantep), 6-1907, M. Haradjian 1264 (E, LE).

10. Crambe shugnana Korsh., Bull. Acad. Imp. Sci. Saint Petersbourg 5 (9.5): 422.1898 (Fig. 7)

Ind. loc.: "Hab. in declivis lapidosis montium, alt. 7-8000'. Schugnan: inter p. Mendy-Schar et Chorog, 27 Jul. (8 Aug.) 97 fl.”.

Type: TAYIKISTAN. Shugnan: inter Mendy-Shar et Khorog, 27-7-1897, Korshinsky 2841, 2842, 2844 (isotypes, LE!).

C. darwasica Korsh., Bull. Acad. Imp. Sci. Saint. Petersbourg 5, ser. 9: 423 (1898)

Ind. loc.: "Hab. in declives lapidosis montium. Darwaz: prope cast. Wancz, alt. 5000', 13 (25) Jun. 97 fl.".

Hemicriptophyte, with thickened and lignified root, and rough stem, covered by hairs, single, solitary or in groups of 6-10 over isolated tubercules, giving the appearance of stellate hairs. Basal leaves with petioles of $15-20 \mathrm{~cm}$, blade $8-18 \times 4-10 \mathrm{~cm}$, from lyratepinnatifid to pinnatisect, coriaceous and rough, margin irregularly serrate, terminal lobe greater, (0)1-3 subtriangular lateral lobes disjointed from the terminal. Sepals oblong with antrorse hairs in the margin and abaxial side. Petals from white to yellow-white, with blade oblong-obovate of 5-5.5 $\times 2.5-3 \mathrm{~mm}$, narrowed in a nail of $0.8-1 \mathrm{~mm}$. Staminal filaments of $\mathrm{c}$. $2.5 \mathrm{~mm}$, with one tooth of $0.2 \mathrm{~mm}$ in upper part. Fruit with proximal joint cylindrical-globose, at times with one developed seed, the distal joint from oblongelliptical to sub-spherical, of $2.5-3 \times 2 \mathrm{~mm}$, slightly strengthened edges, 1-2-seeded.

Habitat and distribution. Rocky ground at 2300$2700 \mathrm{~m}$, in the region of Shugnan (Tajikistan) and in the Pamir Alai (Kyrgyzstan).

\section{Representative specimens}

KYRGYSTAN. Oshskaya Oblast: Pamir Alai, 14-VII-1962, Botchansiev 53 (LE); Selochu-Korgon, 11-V-1963, Ubukieva E Gorbunova (LE). UZBEKISTAN. Bujoro Wiloyati: Alt-Buchara, inter Kazedeh et Shambedeh, c. 8000', 1-VIII-1901, Alexeenko 682 (LE).

11. Crambe gordjaginii Sprygin \& Popov, Pochv. i bot-geogr.nabl.V bass. Amu Dar'i i Syr Dar'i 2: 86.1916 

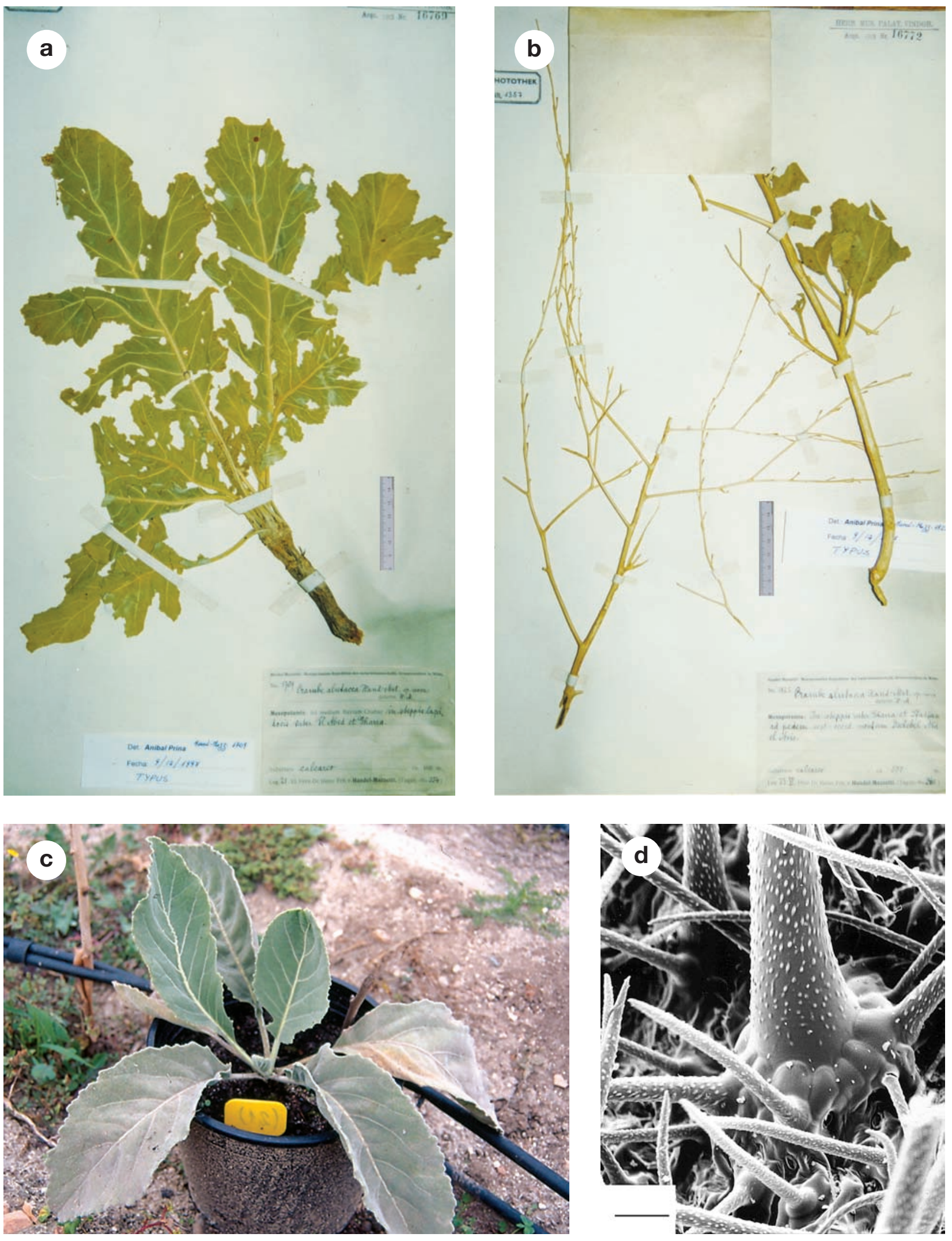

Fig. 6. Crambe alutacea: a, type, Hand.-Mazz. 1709 (isosintype, W); b, type, Hand.-Mazz. 1822 (isosintype, W); c, basal rosette. Grown at ETSIA-UPM; d, base of a foliar trichome. Scale bar $=71.4 \mu \mathrm{m}$. 
Ind. loc.: "Bujara, Tsir-Abadskoie bekstvo: Step Kizirkh-Dar, 23-6-1915, M. G. Popov." (Cyrillic).

Type: holotype?, TASH; cotype, LE (cf. Czerniakowskaya, 1939) (not seen).

Hemicriptophyte of $30-60 \mathrm{~cm}$, with base of stem rugose and lignified. Coriaceous basal leaves, with hirsute petiole from $4-6 \mathrm{~cm}$, blade $5-6 \times 3.5-5 \mathrm{~cm}$, lyrate-pinnatifid, glabrous or with very sparse hairs, frequently reduced to terminal segment or with 1-2 lateral vestiges of segments close to the base. Sepals 3-4 $\times$ 1.5-1.6 mm, glabrous, white-edged. Petals with linear-spathulate blade, gradually narrowing towards the base, yellow, with veins of a more intense yellow colour. Staminal filament of 1.8-2 mm, with lateral teeth at a different height. Fruit with proximal joint $1.5-1.7 \mathrm{~mm}$, cylindrical or slightly swallowed in the middle, the distal joint $2.5 \mathrm{~mm}$ in diameter and up to $3 \mathrm{~mm}$, smooth, single-seeded, flattened seed.

Habitat and distribution. Grows in salty or marlstone soils in the region of the Pamir Alai in Kyrgyzstan and

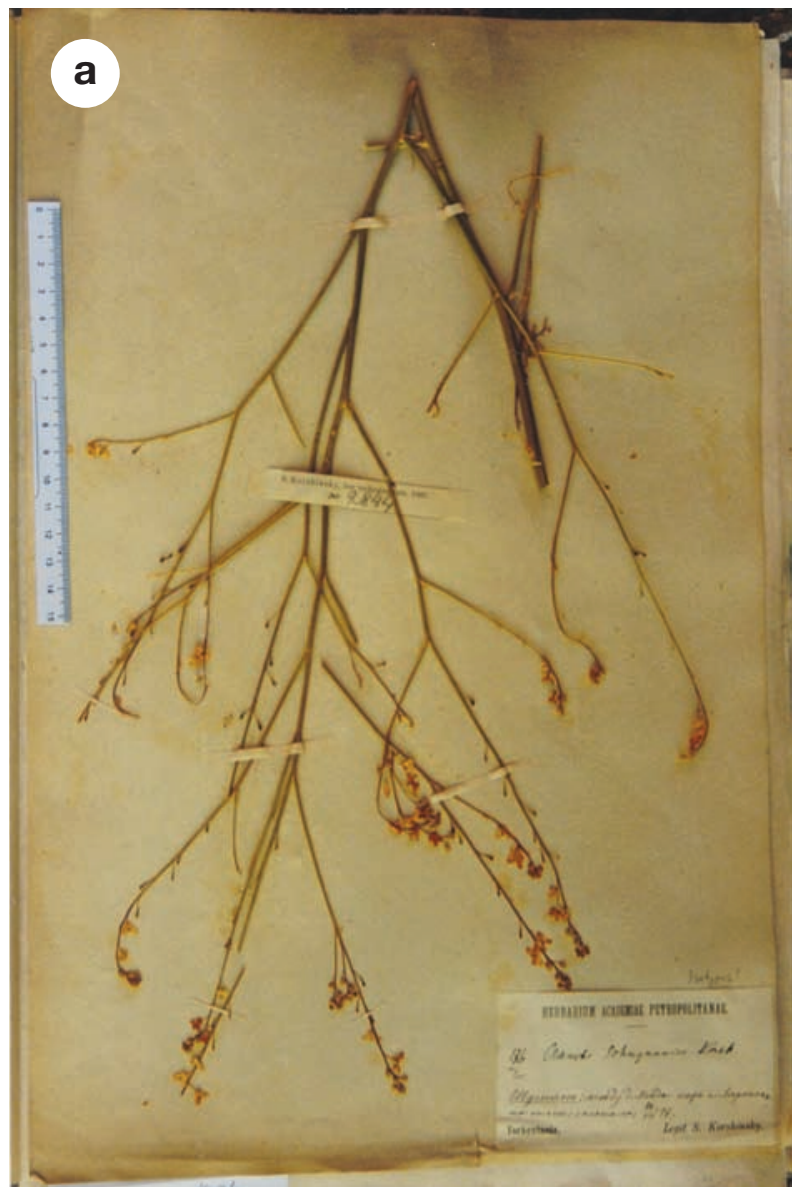

on the steppe of Kyzyryk-Dara, in Uzbekistan; it is here documented for the first time for Afghanistan.

\section{Representative specimens}

AFGHANISTAN. Samangan: 3 miles Hülm in the Tashkurgan gorge, 517 m, 15-V-1969, Hewer 1129 (LE). TAJIKSTAN. gori Jodzha Kazian, 22-V-1960, Nepli s.n. (LE). TURKMENISTAN. 19-VI-1987, Bochantsiev 547 (LE). Lebap Vilayat: Kugitang, 1127 m, 29-V-1977, Bochantsiev 443 (LE).

\section{Crambe orientalis L., Sp. Pl. 2: 671. 1753}

Ind. loc.: "Hábitat in Oriente. Tourn cor. 14".

12a. C. orientalis subsp. orientalis var. orientalis (Fig. 8)

Cochlearia orientalis (L.) Cranz, Class. Cruciform. emend.: 97. 1769

Myagrum orientale (L.) Cranz, Class. Cruciform. emend.: 102. 1769

Crambe quadricostata Boiss., Ann. Sc. Nat. Bot. ser. 2, 17: 388.1842

Ind. loc.: "N. 179, Mesopotamia".

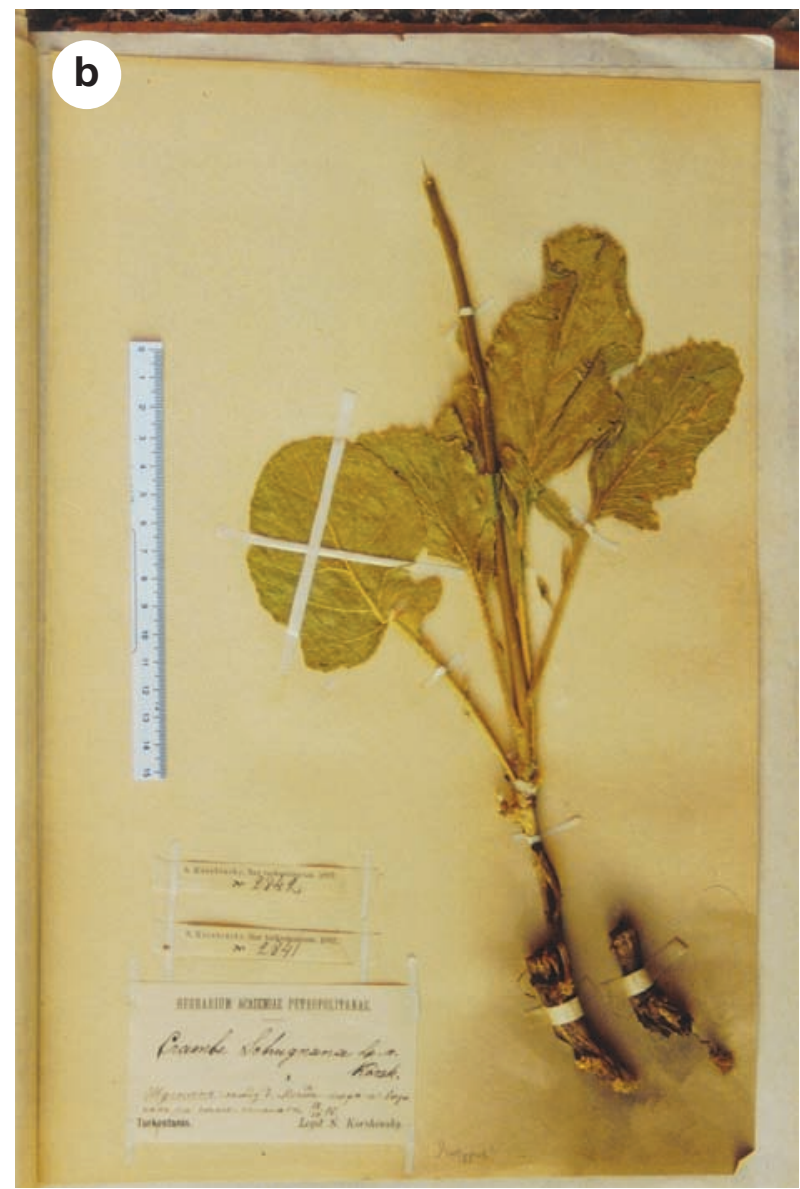

Fig. 7. Crambe shugnana: a, type, Korschinsky 2841 (LE); b, type, Korschinsky 2842 (LE). 
C. aucheri Boiss., Ann. Sc. Nat. Bot. ser. 2, 17: 388. 1842

C. orientalis L. b aucheri (Boiss.) Boiss., Fl. Or. 1: 407. 1867

C. persica Boiss. Ann. Sc. Nat. Bot. ser. 2, 17: 389. 1842

Ind. loc.: "N. 4131, Demavend".

C. juncea Trautv., Acta Horti. Petr. 2: 504. 1873, non M. Bieb. (1819) (cf. Schulz, 1919)

Hemicriptophyte of $90-150 \mathrm{~cm}$, with stems hispid at base. Basal leaves with petiole of $1.5-3 \mathrm{~cm}$, blade ovate-elliptical of $15-10(35) \times 12-14 \mathrm{~cm}$, from indivisive to pinnatifid, with $5-10$ pairs of lateral segments, obovate, acute, irregularly serrate, the terminal similar in size and shape to the laterals, the distal caulines generally individed and sub-sessile, all with patent to sub-adpressed pubescence, very lax. Branches of the inflorescence glabrous or with sparse hairs. Sepals 2.5-2.6 mm, glabrous, yellow-edged. Petals 3-4 × 1$1.5 \mathrm{~mm}$, with oblong-ovate blade, narrowing sharply in a nail 0.3-0.4 mm, white. Staminal filament with one tooth in the upper part. Fruit with proximal joint ovoid-stipitate $0.5-0.7 \mathrm{~mm}$, sterile, the distal joint spherical, with four strengthened edges, $2.5-3 \mathrm{~mm}$ in diameter, single-seeded.

Habitat and distribution. Widely distributed from the Eastern Mediterranean to Central Asia, in steppes and mountains with clay soils, between 300 and $2500 \mathrm{~m}$. Usually behaves as a weed (Zohary, 1966).

\section{Representative specimens}

ARMENIA. Na bieregu oziero Shievan (Cyrillic: side of the Shievan lake), 7-VII-1977, M. K. Stankevich 4532 (VIR). AZERBAIJAN. Transcaucasia: Kazakh, prope p. Dash-Salogly, 24-V-
1937, Gurvitsch s.n. (BM). IRAN. Mazanderan, in valle fluvi Calus, Pol-e-Zanguleh, c. 2200 m, 6-7-VIII-1948, Rechinger 6388 (E, K). ISRAEL. Auranticae: Palestina, Busra, 880 m, 25-III-1932, J.E. Dinsmore 5805 (K). RUSSIA. Dagestán, Derbent ca. Mt. Elbrus, VI-1843, Kotschy 683 (LE). SYRIA. Dimashq: Qatanah, road with Damascus-Beirut road, 27-IV-1945, Norris s.n. (BM). TURKEY. Gümüsane: Zigana, in Zigana daglari ad marginis silv., 22-VIII-1890, P. Sintenis 3407 (K, LE).

12b. C. orientalis subsp. orientalis var. dasycarpa O.E. Schulz in Engler, Pflanzenreich 70: 238. 1919

Ind. loc.: "Cilicien: bei Maaden unweit Bulghar 1300 m ü. M. (W. Siehe n. 560)”.

Type: TURKEY. Içel (Cilicia), bei Maaden unweit Bulghar 1300 m ü. M., 1895-1896, Siehe 560 (isotypes, BM!, E!, K!, LE!).

Plants with a similar aspect to the typical variety but with branches on the inflorescence densely haired and fruit with sparse antrorse hairs.

Habitat and distribution. Shares area with the variety orientalis.

\section{Representative specimens}

Only type specimen studied.

12c. C. orientalis subsp. sulphurea (Stapf ex O.E. Schulz) Prina, stat. nov.

C. orientalis var. sulphurea Stapf ex O.E. Schulz in Engler, Pflanzenreich 70: 238. 1919 [basionym]

Ind. loc.: "Kurdistan: an grasigen Stellen in der Nähe von Süwerek bei Kara-Koei”.

Type: TURKEY. Urfa: Süwerek (Siverek), in herbalis ad Kara Kwei, 24-5-1988, P. Sintenis 743, It. Or. 1888 (E!).
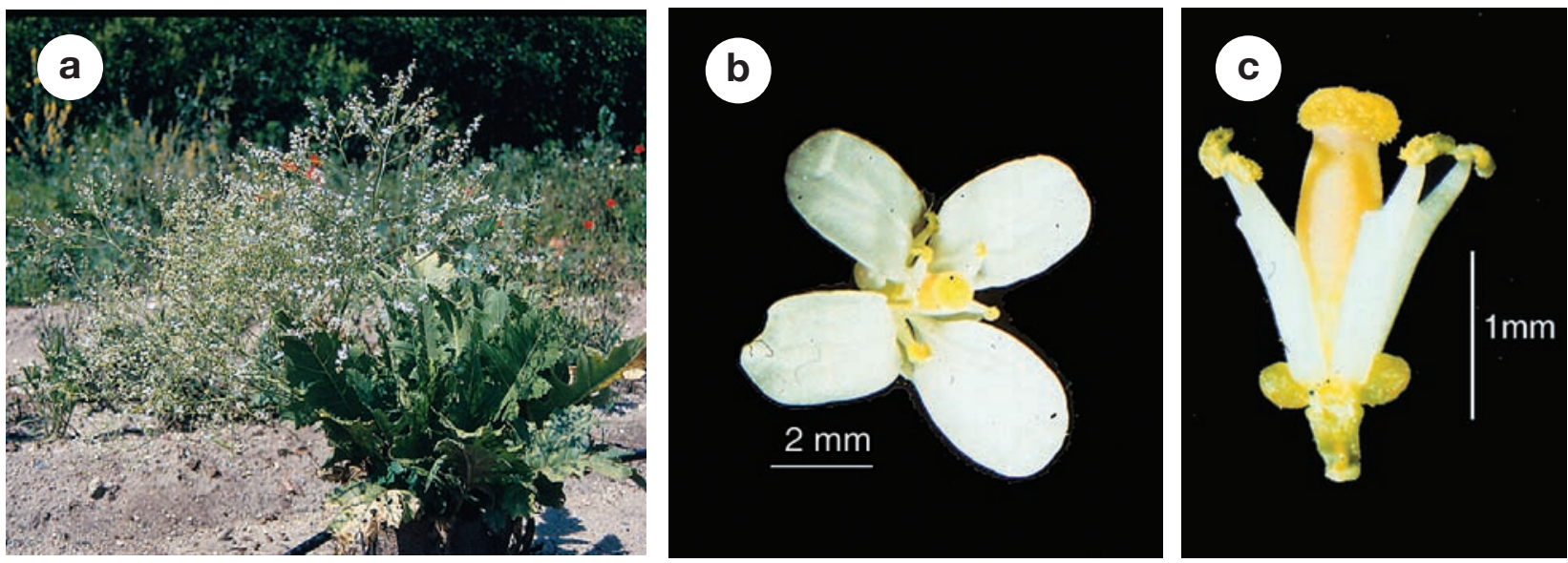

Fig. 8. Crambe orientalis subsp. orientalis. Grown at ETSIA-UPM: a, plant in bloom; b, flower from above; $\mathbf{c}$, flower without perianth. 
C. persica Boiss. var. glaberrima Bornm., Bull. Herb. Boiss., ser. 2(5-1): 56. 1905

C. orientalis L. var. glaberrima (Bornm.) O.E. Schulz in Engler, Pflanzenreich 70: 239. 1919

C. glaberrima (Bornm.) Mouterde, Nouv. Fl. Liban \& Syrie 2: 121. 1970

Ind. loc.: "Elburs occid, in vallibus subalpinis prope Sheheri-tanek, $2200 \mathrm{~m}$ (5.VI, fl. et fr., 7.VII; n 6304). var (nov.) glaberrima Bornm., tota planta glaberrima in consortio praecedentis (n. 6305)".

Type: IRAN. Scheheristanek: Mte. Elburs, 5-61902, Bornmüller 6305 (LE!).

Is differentiated from the subsp. orientalis by the greater size of its petals of 3.8-4.2 $\mathrm{mm}$, the sepals are also tainted yellow, and the general glabrescence of the plant. Given that plants of these characteristics have a defined area of distribution, it was decided to propose the subspecific status.

Bornmüller (1905) describes C. persica var. glaberrima based on the specimen Bornmüller 6305, indicating in the protologue "Tota planta glaberrima". Later, Schulz (1919) transfers the variety to C. orientalis and Mouterde (1970) gives it the rank of species. The indumentum of the species is extremely variable, from totally glabrous to totally hairy plants. The stems are in general glabrous and smooth, although there are specimens which have striated stems with retrorse hairs. The presence or absence of indumentum on the stems is independent of the hairiness of the leaves, just as it is independent of the variety to which they belong. There are also totally glabrous specimens which may be confused with $C$. pinnatifida. The following material studied presents hairs on the stems: Wendelbo 1302 (E), Archibald 2346 (E), Davis 47241, 19175 and 43674 (E), Mannissadiian 776 (E), Davis 28232 (BM), De Heldreich s.n. (BM), Haussknecht s.n. (BM, var. orientalis) and Sintenis 743 (E, var. sulphurea).

Habitat and distribution. Desert areas in the region of Kurdistan.

\section{Representative specimens}

IRAQ. Dahuk: Mahmur Dag, 700 m, 20-IV-1951, B. Gillett 11230 (K). SPAIN. Madrid: Cult. Hort. E.T.S.I. Agrónomos U.P.M., ex sem. Bansem-UPM 6247 (sub C. orientalis), 1-VIII1998, A. Prina 267 (MA 626713). TURKEY. Mardin: Gizre to Hezzana, at $\mathrm{S}$ foot of Cudi daglari, 500-700 m, 10-V-1966, Davis $42766(\mathrm{E})$.

13. Crambe grossheimii I.I. Khalilov, Bot. Zhurn. 75(11): 1572. 1990
Ind. loc.: "Caucasus, Transcaucasia australis, RSSA Nakhitschevan, prope salifodinam”.

Type: AZERBAIJAN. Nachicevan: prope salifodinam, 22-6-1987, I. Khalilov 17 (LE!).

Hemicriptophyte of $30-50 \mathrm{~cm}$, with caudex from which grow several stems with stiff hairs, from patent to retrorse at the base. Basal leaves with petiole of 4-6 $\mathrm{cm}$, hispid and highly canaliculate, with blade of 6-7 $\times$ 4-5 $\mathrm{cm}$, obovate, irregularly serrate, lyrate-pinnatifid with the terminal segment noticeably larger than the laterals, these latter at times absent, with hispid hairs on both sides. Sepals 2-2.5 mm, glabrous. Petals 3-3.5 $\mathrm{mm}$, with obovate blade and short nail, white. Staminal filament with one incurved apical tooth. Fruit with stipitate proximal joint of $1.8-2 \mathrm{~mm}$, sterile, the distal joint globose, spherical, $2.8-3 \mathrm{~mm}$ in diameter, smooth, single-seeded.

Habitat and distribution. Characteristic species of salty soil to $\mathrm{S}$ of Caucasus and $\mathrm{S}$ of Turkmenistan.

\section{Representative specimens}

TURKMENISTAN. Balkanskiy Velayat: Kizil-Atrek, 24-V1928, Bobrov E Jarmolenko 50 (LE).

14. Crambe hedgei I.I. Khalilov, Bot. Zhurn. 75(8): 1169. 1990

Ind. loc.: "Afganistan, Malestan, Ghazni, Inter Miradina et jugum Ghoutem Kol, N Sangi-Masha, $33^{\circ} 30^{\prime} \mathrm{N}, 67^{\circ} 5^{\prime} \mathrm{E}$, c. $3300 \mathrm{~m}, 2-7-1962^{\prime \prime}$.

Type: AFGHANISTAN. Malestan, Ghazni, Inter Miradina et jugum Ghouten Kol, N Sangi-Masha, $33^{\circ} 30^{\prime} \mathrm{N}, 67^{\circ} 5^{\prime} \mathrm{E}$, c. 3300 m, 2-7-1962, K. H. Rechinger $17604(\mathrm{~W} !)$

C. orientalis sensu Hedge en K.H. Rechinger, Fl. Iranica 57: 48. 1968, proparte

Hemicriptophyte of $60-90 \mathrm{~cm}$, with leafy stems from the base, finely pubescent. Basal leaves with petiole of $6-10 \mathrm{~cm}$, and blade of $15-35 \times 5-8 \mathrm{~cm}$, ovatelanceolate, highly pinnatilobed, with $8-12$ pairs of subtriangular lateral segments $0.5-2.5 \mathrm{~cm}$, with velutinous pubescence on both sides; caulines similar to basal leaves, somewhat smaller in size towards the apex. Sepals 3.5-4 mm, glabrous, yellowish-green. White petals, with blade 4.5-6 $\times 2.5-3 \mathrm{~mm}$, oblong, and obtuse apex, nail $0.3-0.4 \mathrm{~mm}$. Staminal filaments without subapical tooth. Fruit with proximal joint short obconical, 0.8-0.9(1) $\mathrm{mm}$, sterile, with no vestiges of seeds, the distal joint spherical $2.5-3 \mathrm{~mm}$ in diameter, smooth surface or at times slightly strengthened edges, single-seeded. 
Habitat and distribution. Grows on rocky and arid hills of N Afghanistan, between 2000 and $3000 \mathrm{~m}$.

\section{Representative specimens}

AFGHANISTAN. Bamiyan: ca. $10 \mathrm{~km}$ E of crossing to north to Dosi on the road of Charikar to Bamiyan, 2-VII-1972, Pertti Uottila 18727 (E).

15. Crambe koktebelica (A. Junge) N. Busch, Fl. Cauc. crit. 4(3): 296. 1909

C. juncea var. koktebelica A. Junge, Trav. Soc. nat. St. Petersb. 35(6): 395.1904 [basionym]

C. orientalis var. koktebelica (A. Junge) O.E. Schulz in Engler, Pflanzenreich 70: 239. 1919

Ind. loc.: "Tiflis, Elizabethpol vi Teguerana" (Cyrillic in the original)

Type: UKRAINE. Crimea: Tauria, Koktebell, 15-51906 fl. 12-6-1906 fr., A. Junge (phototype, LE!).

C. mitridatis Juz., Bot. mater. Gerb. Bot. Inst. Komarova Acad. Nauk S.S.S.R. 14: 9. 1951

C. orientalis var. mitridatis (Juz.) Kotov, Visn. rosl. Ukr. 2: 234. 1965

Ind. loc.: "In calcareis peninsula Kertsch".

Type: Peninsula Kertsch mons Opuk (mare Nigrum) in calcareis, in fisuris, 22-5-1906, fl., fr., B. Klopotov.

Hemicriptophyte of 1.5-2.5 m; base with very dense and retrorse pubescence in young plants, glabrous or with very short hairs and sparse in adult plants. Basal leaves petiolate, blade $20-30(60) \times 9-8(25) \mathrm{cm}$, discolour, lighter on the lower side, ovate-elliptical, pinnatisect, with 4-6 pairs of lateral segments, with dense pubescence of hairs from stiff to lying on both surfaces, the caulines of $2-5 \mathrm{~cm}$, sparse, very reduced, from linear to oblanceolate. Upright pedicels, never adpressed. Sepals 2-2.5 mm, glabrous, colour green glabrous. Petals 4.5-5.5 mm, with obovate blade, sharply narrowing in a nail of c. $0.3 \mathrm{~mm}$, white. Staminal filaments with one subapical tooth of c. $0.3 \mathrm{~mm}$. Fruit with proximal joint short obconical, of 1-1.4 mm, with aborted seed primordia, the distal joint globose, with dark and prominent veins which give it a slightly rugose quality, of 3.5-4 $\mathrm{mm}$ in diameter, single-seeded.

Habitat and distribution. Grows on the Taman peninsula and the coasts of Ukraine on the Azov Sea and the Black Sea, and in Russia in the region of the Volga delta on limestone-clay soils.

\section{Representative specimens}

RUSSIA. Kalmyckaja: Astrakan, Ergeni prope cabinam “Manykski Ulus”, 17-VI-1926, Kazakevicz 2913 (LE). UKRAINE.
Crimea: Tauria Koktebell, in steppis 27-IV-1903, Golde s.n. (BM). Tarchankut, ca. Olenevka, 26-V-1984, Tsevelev \& al. 1251 (LE).

This is a species related to C. juncea and to C. orientalis. It was described as a variety of the first taxon and later elevated by Busch (1909) to the rank of species, a criterion followed by Czerniakowskaya (1939); it was also considered as a variety of C. orientalis (Schulz, 1919). Its specific status is supported by the larger size of its flowers compared to C. orientalis, its rougher and shorter hairiness than that of $C$. juncea; furthermore it grows in coastal areas of marine influence where neither of the other species are to be found.

16. Crambe juncea M. Bieb., Fl. Taur.-Cauc. 3: 421. 1819

C. orientalis var. juncea (M. Bieb.) O.E. Schulz in Engler, Pflanzenreich 70: 238. 1919

Ind. loc.: "Habitat in Iberia"

Type: GEORGIA. Tbilisi, ex Herb. Marschal Bieberstein (LE!).

C. buxbaumii Willd. ex Ledeb. Fl. Ross. 1: 222. 1842

Ind. loc.: "Hab. in Iberia! (Adams in Willd. herb., Wilhelms), prov. Talüsch alt. 670 hexap. (C.A. Meyer)". Type: Willd. herb. n. ${ }^{\circ} 11758$.

C. juncea var. aculeolata N. Busch, Fl. Cauc. crit. 3(4): 299. 1909

C. aculeolata (N. Busch) Czerniak. in Komarov, Flora of U.S.S.R., add. 7: 488. 1939

C. orientalis var. juncea f. aculeolata (N. Busch) O.E. Schulz in Engler, Pflanzenreich 70: 239. 1919

Ind. loc.: "In der Gegend von Nachitschewan (Radde nach Busch)".

Typus: AZERBAIJAN. Nachicevan, prope Belev, 17-6-1871, Fl. Fr. imm., Rade (LE!).

Hemicriptophyte up to $1.2 \mathrm{~m}$., with roots with capacity to resprout, and hirsute basal rosette. Basal leaves with hirsute and pungent petiole, with blade 15 $40 \times 8-20 \mathrm{~cm}$, ovate-elliptical, individed, irregularly sinuate-serrate in proximal leaves, later lyrate-pinnafitid to pinnatipartite, with 7-9 lateral segments, hirsute specially in the beam, the caulines similar although smaller and tending towards glabrous. Pedicel adpressed. Sepals 1.5-2 mm, glabrous, yellowish-green, lightly edged white. Petals white oblong, with blade $4.5-5 \mathrm{~mm}$, sharply narrowing in a nail of $0.5 \mathrm{~mm}$. Staminal filaments $2.5 \mathrm{~mm}$, with one subapical tooth facing that of the opposite filament. Fruit with proximal joint cylindrical 1-1.5 $\mathrm{mm}$, the distal joint subspherical, smooth, 3-4 mm in diameter, single-seeded. 
Habitat and distribution. Arid hills and slopes of Armenia between 300 and $1300 \mathrm{~m}$, north-eastern region of Caucasus and $\mathrm{N}$ of Iran.

\section{Representative specimens}

ARMENIA. Oziero Shievan (Shievan lake), 8-VII-1970, CCCP ex Herb. Komarov (BM). AZERBAIJAN. Nagorno Karabaj: 2-VII1971, Stankevich s.n. (VIR). GEORGIA. Elizabethpol, VI-1834, Hohenacker s.n. (BM). IRAN. Azerbaijan-e-sharqui: in collibus Sahand, 6000 ft. 26-VI-1929, Cowan E Darlington 1856 (K). SPAIN. Madrid: Cult. Hort. E.T.S.I. Agrónomos U.P.M., ex sem. U.S.D.A.-NCRPIS 325.274, 25-IV-1998, A. Prina 1003 (MA).

Busch (1909) described the var. aculeolata based on aculeate petioles and stems, later it was elevated to the rank of species by Czerniakowskaya (1939) and maintained at that rank by Khalilov (1993). The study of the type specimens of $C$. juncea and C. aculeolata has demonstrated that the taxonomical value of the latter is also to be found in the type specimen of $C$. juncea, for which reason they have been considered synonyms.

\section{Dubious taxa and names}

C. parviflora Hub.-Mor. \& Reese, Feddes Repert. Spec. Nov. Regni Veg. 48: 276. 1940

C. tataria Sebeók var. parviflora (Hub.-Mor. \& Reese) Hedge \& Hub.-Mor., Notes Royal Bot. Gard. Edinburgh 26: 181. 1965

Ind. loc.: "Kleinasien; Phrygien zwischen Usak und Salihli, ca. $20 \mathrm{~km}$ westlich von Usak, 900 m, 8.VI.35, leg. H. Reese, E. Wall".

Huber-Morath \& Reese (1940) described C. parviflora on the basis of a sample collected in the region of Phrygia, in W Turkey. They pointed to similarities with C. aspera and differentiated it from C. tataria by the smaller size of its organs, especially the flowers. Later, this species was reduced to a variety of $C$. tataria by Hedge \& Huber-Morath (1965). A few specimens of this region have been detected with small flowers, but do not coincide with C. parviflora in its other traits, above all because some of these individuals have mature fruit of the same size as that frequently found in C. tataria. Khalilov (1993) syonimizes it with the typical variety of this species. Given the great morphological variability of the group "tataria", we think it convenient to consider this taxon as dubious for the moment, until such time as the study of a greater number of specimens may confirm its status.

C. suecica Mill., Gard. Dict. Hort. ed. 8: Cra. 2. 1768

Miller (1768) describes this taxon with the indication "foliis profunde laciniatis, caule erecto, ramoso.
Sea Cabbage with leaves deeply cut, and an upright bran king stalk". This is probably a synonym of $C$. maritima L., but as the description offers so little information and as the author in the same work consigns C. maritima to a different taxon, we have decided to keep this name as dubious.

\section{Acknowledgements}

This study was undertaken in the context of a doctoral thesis carried out in the Escuela Técnica Superior de Ingenieros Agrónomos, at the Universidad Politécnica de Madrid, under the direction of Dr. Juan Martínez-Laborde. The author wishes to thank the staff of the herbaria consulted, the directors of the germplasm banks, who provided material for cultivation, Dr. Adrián Escudero-Alcántara and Dr. Juan Martínez-Laborde for their critical reading of the manuscript and the reviewers and editors for their valuable observations.

\section{References}

Bornmüller. 1905. Beiträge zur Flora Elbursgebirge Nord-Persiens. In: Beauverd, G. (dir.), Bulletin de l'Herbier Boissier 5, serie 2: 49-57.

Busch, N. 1909. In: Kusnezow, N. (ed.), Flora Caucasus Criticae. 3(4): 299-301.

Candolle, A.P. de. 1821. Crambe L. Regni vegetabilis systema naturale 2: 650-656. Paris.

Czerniakowskaya, E.G. 1925.”Noviie i redkie rasteniia Zakasniia”. Izvestiya Glavnogo Botanicheskogo Sada SSSR 24: 120.

Czerniakowskaya, E.G. 1929."Zametka o vidaj Crambe iz Turkmienistana”. Izvestiya Glavnogo Botanicheskogo Sada SSSR 28 (3-4): 395-399.

Czerniakowskaya, E.G. 1939. Crambe L. In: Komarov, V.L. (ed.), Flora of the URSS 8: 475-492 Akademiya Nauk S.S.S.R., Moscou. (Translated from Russian by the Israel Program for Scientific Translations. 1970). Jerusalem.

Dinsmore, J. 1932. Crambe L. In: Post, G.E. (ed.), The Flora of Syria, Palestine and Sinai $1.2^{\mathrm{a}}$ ed. by J. Dinsmore. American Press. Beirut.

Francisco-Ortega, J., Fuertes-Aguilar, J., Gómez-Campo, C., Santos-Guerra, A. \& Jansen, R. 1999. Internal transcribed spacer sequence phylogeny of Crambe L. (Brassicaceae): Molecular data reveal two Old World disjunctions. Molecular Phylogenetics and Evolution 2(3): 361-380.

Francisco-Ortega, J., Fuertes-Aguilar, J., Seung-Chul, K., SantosGuerra, A., Crawford, D.J. \& Jansen, R.K. 2002. Phylogeny of the Macaronesian endemic Crambe section Dendrocrambe (Brassicaceae) based on Internal Transcribed Spacer Sequences of Nuclear Ribosomal DNA. American Journal of Botany 89(12): 1984-1990.

Freyn, J.F. 1903. In: Beauverd, G. (dir.), Plantae ex Asia Media. Bulletin de l'Herbier Boissier 3, serie 2: 857-859.

Green, M.L. 1925. Standard-Species of the Linnean genera of Tetradynamia. Bulletin of Miscellaneous Information, Royal Gardens, Kew, 2: 49-58.

Hedge, I. 1968. Cruciferae. In: Davis, P.H. (ed.), Flora of Turkey and east Aegean Islands 1: 272-273. Edinburgh University Press, Edinburgh. 
Hedge, I. 1993. A list of Linnaean generic names and their types. In: Jarvis, C.E., Barrie, F.R., Allan, D.M. \& Reveal, J.L. (eds.), Regnum Vegetabile 127: 1-100.

Hedge, I. \& Huber-Morath, A. 1965. Cruciferae. In: Davis, P.H. $\&$ al. (eds.), Materials for a flora of Turkey 10. Notes from the Royal Botanic Garden, Edinburgh 26(2): 181.

Huber-Morath, A. \& Reese, H 1940. In: Huber-Morath, A., Novitiae Florae Anatolicae 2. Feddes Repertorium Speciarum Novarum Regni Vegetabilis 48: 276-277.

Jafri, S.M.H. 1973. Brassicaceae. In: Nazir, E. \& Ali, S. J. (ed.), Flora of West Pakistan 55: 1-308. Karachi.

Jalas, J., Suominen,J. \& Lampinen, R. 1996. Atlas Flora Europaeae, distribution of Vascular Plants in Europe 11, Committee for Mapping the Flora of Europe and Societas Biologica Fennica Vanamo. Helsinki.

Khalilov, I. 1991a. Generis Crambe L. (Cruciferae) sectiones tres novae. Novosti Sistematiki Vysshikh i Nizshikh Rastenii, Kiev 28: 78-79.

Khalilov, I. 1991b. Sistema roda Crambe (Brassicaceae). Botanicheskii Zhurnal 76(11): 1612-1613.

Khalilov, I. 1993. A synopsis of the genus Crambe (Brassicaceae). Botanicheskii Zhurnal 78 (1): 107-115.

Khalilov, I. \& Archangelsky, D.B. 1991. Palynological studies in the species of the genus Crambe (Brassicaceae) in connection with its systematics. Botanicheskii Zhurnal 76(11): 1582-1586.

Leppik, E. \& White, G. 1975. Preliminary Assessment of Crambe germplasm resources. Euphytica 24: 681-689.

Miller, P. 1768. The Gardener's Dictionary. 8 ed. London. UK.
Mouterde, P. 1970. Nouvelle Flore du Liban et de la Syrie 2, text and atlas. Beyrouth.

Planellas, J. 1852. Ensayo de una flora fanerogámica gallega. 450 pp. Santiago de Compostela.

Prantl, K. 1891. Cruciferae. In: Engler, A. \& Prantl, K. (ed.), Die Natürlichen Pflanzenfamilien 3(2): 145-206. Leipzig.

Prina, A. 1998. The status of Crambe alutacea Hand.-Mazz. (Cruciferae, tribe Brassicaceae). Flora Mediterranea 8: 25-29.

Prina, A. 1999. A taxonomic revision of Crambe, sect. Leptocrambe (Brassicaceae). Botanical Journal of the Linnean Society 133 (4): 509-524.

Prina, A. 2000. Revisión Taxonómica del Género Crambe L. (Brassicaceae, Brassiceae). Tesis doctoral inédita. Universidad Politécnica de Madrid. Madrid.

Prina, A. \& Martínez-Laborde, J.B. 2008. A taxonomic revision of Crambe section Dendrocrambe (Brassicaceae). Botanical Journal of the Linnean Society 156: 291-304.

Ruprecht, F.J. 1869. Flora Caucasi. 1. Mémoires de l'Académie Impériale des Sciences de Saint Pétersbourg, serie 7, 15(2): 135-136.

Schulz, O.E. 1919 (Neudruck, 1959). Crambe L. In: Engler, A., (ed.), Das Pflanzenreich 70: 228-249. Leipzig, Weinheim.

Scott, G.A.M. \& Randall, R.E. 1976. Biological Flora of the British Isles. Crambe maritima L. Journal of Ecology 64: 1077-1091.

Zohary, M. 1966. Cruciferae. In: Zohary, M. (ed.), Flora of Palaestina 1 (text): $246-329+1$ (plates): 365-480. The Israel Academy of Sciences and Humanities. Jerusalem.

Editor asociado: Ramón Morales Recibido: 23-IV-2008 Aceptado: 10-XI-2008 